Article

\title{
Impact of Sulphate Ions Content on Performance of Maleic and Acrylic Superplasticizers in Cement Paste
}

\author{
Elżbieta Janowska-Renkas
}

check for updates

Citation: Janowska-Renkas, E. Impact of Sulphate Ions Content on Performance of Maleic and Acrylic Superplasticizers in Cement Paste. Materials 2021, 14, 2683. https:// doi.org/10.3390/ma14102683

Academic Editor: Alexandra Bertron

Received: 25 March 2021

Accepted: 17 May 2021

Published: 20 May 2021

Publisher's Note: MDPI stays neutral with regard to jurisdictional claims in published maps and institutional affiliations.

Copyright: (C) 2021 by the author. Licensee MDPI, Basel, Switzerland. This article is an open access article distributed under the terms and conditions of the Creative Commons Attribution (CC BY) license (https:// creativecommons.org/licenses/by/ $4.0 /)$.
Department of Building Materials Engineering, Faculty of Civil Engineering, Opole University of Technology, Katowicka 48, 45-061 Opole, Poland; e.janowska-renkas@po.edu.pl

Abstract: The paper presents test results of the impact of sulphate ions from calcium sulphates: Hemihydrate, dihydrate and anhydrite, on rheological properties and hydration heat of cement pastes with, and without, superplasticizers, derivatives of maleic (SP-2) and acrylic (SP-1) acids. It is demonstrated that cement pastes fluidity depends on superplasticizer chemical structure, and its effect is expressed by a hydrophilic coefficient. As maleic superplasticizers have flexible comblike structure composed of a shorter backbone chain containing $\mathrm{COO}^{-}$carboxylate groups and very long side chains, cement pastes showed higher fluidity than with acrylic superplasticizer with ladder-like structure, longer backbone chains with shorter side chains. SP-1 showing lower hydrophilicity coefficient and fewer $\mathrm{COO}^{-}$groups was found to be less sensitive to increased sulphate ion content in pastes. However, with SP-2 with higher hydrophilicity, a gradual fluidity loss (increased paste viscosity) was observed. Plastic viscosity was approximately at the same level in SP-1-containing pastes. Tests showed that sulphates definitely changed polycarboxylate superplasticizers performance. A high concentration of sulphate ions reduced maleic superplasticizer efficiency. Under these conditions, SP-1 is more effective and therefore more suitable for fluidity of pastes containing higher $\mathrm{SO}_{4}{ }^{2-}$ ions content. Thus, sulphate ions concentration in the paste should be considered when selecting superplasticizer.

Keywords: cement; Calcium Sulphate $\left(\mathrm{CaSO}_{4} ; \mathrm{CaSO}_{4} \cdot 2 \mathrm{H}_{2} \mathrm{O}\right.$ and $\left.\mathrm{CaSO}_{4} \cdot 0.5 \mathrm{H}_{2} \mathrm{O}\right)$; rheology; calorimetry; acrylic superplasticizer; maleic superplasticizer chemical structure SP; hydrophilicity of SP polymer

\section{Introduction}

Rheological properties of the cement paste depend on the amount and form of the calcium sulphate applied as a setting time regulator. The setting time regulator, when properly selected, assures effective regulation of $\mathrm{C}_{3} \mathrm{~A}$ hydration process, which is demonstrated by the increased fluidity of the cement paste [1-3].

The introduction of superplasticizers to cementitious paste increases their fluidity and delays the cement hydration process suitably to the superplasticizer efficiency that depends on the performance mechanism. The performance mechanism of various types of superplasticizers has been described by numerous authors [4-6].

Currently applied new-generation superplasticizers are based on polycarboxylates (PC), copolymers of the acrylic acid with acrylates (CAE), as well as cross-linked acrylic resins (CLAP). They are built of a polyacrylic or polymethacrylic backbone chain containing side chains formed by carboxylate groups, polyoxyethylene, polyoxypropylene or polyether, ether-ester mers (units) or their mixtures [7-9]. Mechanism of their functioning, despite an electrostatic repulsive force of the same sign charges that are formed on the cement grain surface in result of superplasticizer adsorption, is associated with an effect of a spatial spherical blockade-created by long side poly(oxyethylene) chains present in the structure of these superplasticizers [10-14]. 
Efficiency of these superplasticizers may be affected by numerous factors depending on, besides others, their molecular structure, including; length and type of the backbone chain, length, number and density of side chains, presence of hydrophilic and hydrophobic groups in side chains, polymerisation degree and energy of adsorption bonds [13,15-24].

The interactions within cement-additive system-degree of the paste fluidity-are also determined by the superplasticizer form and its place within cement paste (organicmineral phase, OMP), hydrated surface of cement grains or non-adsorbed form in the water phase [25].

The above was confirmed by research conducted by Uchikawa [26], which showed that the lower adsorption of the superplasticizer affected the growth of cement paste fluidity. Whereas, Jolicoeur et al. [27], proved the paste fluidity is proportional to the concentration of free (non-adsorbed) superplasticizer left in the cement paste solution.

According to former studies, the calcium sulphates added to the cement as the setting time regulator can react with superplasticizers, but these interactions may take different forms.

It should be emphasized that as both acceleration and delay, as well as no impact of the superplasticizer are noted in many papers, and in that, respect there is no clear answer.

The quantity and reactivity of $\mathrm{C}_{3} \mathrm{~A}$ phase also have the influence on rheological properties of pastes with regard to the superplasticizer [28].

It results from the fact that calcium sulphates react with a tricalcium aluminate and depending on the content and type (hemihydrate or dihydrate) of the sulphate used, they delay hydration of the tricalcium aluminate to varying degrees, thus accelerating hydration of silicates [1-3]. Whereas, the quantity of gypsum required in the hydration process grows along with the content of $C_{3} A$ and alkalis [29,30]. A similar effect was found by authors of papers [31-33] for pastes in presence of the superplasticizer.

According to Roberts et al. [34], large concentration of the $\mathrm{C}_{3} \mathrm{~A}$ phase and low accessibility of the sulphate ions in a paste, in presence of superplasticizer, deteriorates the rheological properties. On the other hand, large amount of $C_{3} A$ causes enhanced adsorption of superplasticizer on the $\mathrm{C}_{3} \mathrm{~S}$ or $\mathrm{C}_{2} \mathrm{~S}$ phase grains, thus, improving pastes rheological properties.

Whereas, according to Pourchet et al. [25], low reactivity of the $\mathrm{C}_{3} \mathrm{~A}$ phase during the first hydration period leads to deterioration of rheological properties of pastes. This is caused by building the superplasticizer molecules into the products of aluminates hydration and consequently by decrease of the polymer amount available to dispergate the cement particles agglomerates.

Many authors, including Grierson et al. [28], Jolicoeur et al. [35], Sakai et al. [36] found that the superplasticizer may block reactions of sulphate ions coming from gypsum with $\mathrm{C}_{3} \mathrm{~A}$ phase, which in consequence led to a competitive reaction of the superplasticizer with the tricalcium aluminate. The competitive adsorption of sulphate ions on the surface of hydrated $\mathrm{C}_{3} \mathrm{~A}[37,38]$ causes (in the first $30 \mathrm{~min}$. of the hydration period) that a larger quantity of the superplasticizer is built into the organic-mineral phase (OMP) at the small quantity of $\mathrm{SO}_{4}{ }^{2-}$ ions. It causes a reduced quantity of the superplasticizer required for effective dispersion of cement particles. On the other hand, if the sulphate ions quantity is sufficient, a larger quantity of superplasticizer polymer particles causes enhanced fluidity of cement pastes [24].

This is also confirmed by the results obtained by Hanna et al. [39] who proved that at the small calcium sulphate dissolution rate, superplasticizer molecules tend to adsorb on aluminates, thus preventing ettringite formation reaction. To prevent superplasticizer molecules interference into the ettringite formation process, the authors of this paper are of the opinion that better accessibility of $\mathrm{SO}_{4}{ }^{2-}$ ions in the solution is necessary during hydration. Therefore, the suitable calcium sulphate dissolution rate, adjusted to $\mathrm{C}_{3} \mathrm{~A}$ phase reactivity, is so important. Furthermore, the dissolution rate of calcium sulphates becomes lower in the presence of sulphate ions from superplasticizer function groups. 
Whereas, according to research conducted by Nakajama and Yamada et al. [37], along with the growth of sulphate ions in the solution, the quantity of superplasticizer molecules adsorbed on the cement grains is reduced, leading to lower fluidity of cement pastes. It is also confirmed by Pourched et al. [25].

According to the above review, influence of the sulphate ions (originated from the sulphates displaying different dissolution rate) on efficiency of the new-generation superplasticizers is still not clear despite intensive researches.

Due to diverse opinion, this study tries to explain the relation between sulphate ions concentration (which depends, in turn, on the dissolution rate of sulphates applied) and the efficiency of the new-generation superplasticizers that base on polycarboxylic ethers of various chemical and molecular structure.

\section{Materials and Methods}

Material used for testing was cement prepared in a lab by grinding the industrial clinker together with the setting time regulator.

Chemical and mineral composition of the clinker and the specific surface area are shown in Table 1. The specific surface area of clinker was determined acc. to Blaine and was $314.0 \mathrm{~m}^{2} / \mathrm{kg}$.

Table 1. Chemical and mineral composition of clinker $(\mathrm{K})$ and its Blaine specific surface.

\begin{tabular}{|c|c|c|c|c|c|c|c|c|c|c|c|c|c|c|c|}
\hline Component & $\mathrm{SiO}_{2}$ & $\mathrm{Fe}_{2} \mathrm{O}_{3}$ & $\mathrm{Al}_{2} \mathrm{O}_{3}$ & $\mathrm{CaO}$ & $\mathrm{MgO}$ & $\mathrm{SO}_{3}$ & $\mathrm{Na}_{2} \mathrm{O}$ & $\mathrm{K}_{2} \mathrm{O}$ & $\mathrm{Cl}^{-}$ & $\mathrm{CaO}_{\text {free }}$ & $\mathrm{C}_{3} \mathrm{~S}$ & $\mathrm{C}_{2} \mathrm{~S}$ & $\mathrm{C}_{4} \mathrm{AF}$ & $\mathrm{C}_{3} \mathrm{~A}$ & $\begin{array}{l}\text { Blaine } \\
\text { Surface } \\
{\left[\mathrm{m}^{2} / \mathrm{kg}\right]}\end{array}$ \\
\hline $\begin{array}{c}\text { Clinker K } \\
{[w t \%]}\end{array}$ & 21.0 & 3.1 & 5.3 & 65.9 & 0.8 & 1.4 & 0.1 & 0.9 & 0.04 & 0.3 & 66.0 & 11.0 & 10.0 & 8.7 & 314.0 \\
\hline
\end{tabular}

As the setting time regulator, various forms of calcium sulphates were used $\left(\mathrm{CaSO}_{4}\right.$, $\mathrm{CaSO}_{4} \cdot 2 \mathrm{H}_{2} \mathrm{O}$ and $\mathrm{CaSO}_{4} \cdot 0.5 \mathrm{H}_{2} \mathrm{O}$ ) and additionally mixtures of $\mathrm{CaSO}_{4}$ and $\mathrm{CaSO}_{4} \cdot 0.5 \mathrm{H}_{2} \mathrm{O}$ sulphates in amount of $5 \%$ by mass.

The quantity of $\mathrm{CaSO}_{4}$ in the mixture fluctuated from 20 to $80 \%$ by mass. In all cements made the total quantity of sulphates introduced into cements was the same and it amounted to $2.33 \% \mathrm{SO}_{3}$ (Table 2).

Table 2. Composition of cements for testing.

\begin{tabular}{|c|c|c|c|c|c|}
\hline \multirow{2}{*}{ Cement } & \multirow{2}{*}{ Type of Cement Setting Regulator } & \multirow{2}{*}{$\begin{array}{c}\text { Clinker } \\
\text { [\% by Mass] }\end{array}$} & \multicolumn{3}{|c|}{$\mathrm{SO}_{3}$ Content [ $\%$ by Mass] } \\
\hline & & & $\mathrm{CaSO}_{4}$ & $\mathrm{CaSO}_{4} \cdot 0.5 \mathrm{H}_{2} \mathrm{O}$ & $\mathrm{CaSO}_{4} \cdot 2 \mathrm{H}_{2} \mathrm{O}$ \\
\hline $\mathrm{C} 1$ & $100 \% \mathrm{CaSO}_{4} \cdot 0.5 \mathrm{H}_{2} \mathrm{O}$ & 95.8 & - & 2.33 & - \\
\hline $\mathrm{C} 2$ & $100 \% \mathrm{CaSO}_{4}$ & 96.0 & 2.33 & - & - \\
\hline $\mathrm{C} 3$ & $100 \% \mathrm{CaSO}_{4} \cdot 2 \mathrm{H}_{2} \mathrm{O}$ & 95.0 & - & - & 2.33 \\
\hline CM1 & $20 \% \mathrm{CaSO}_{4}+80 \% \mathrm{CaSO}_{4} \cdot 0.5 \mathrm{H}_{2} \mathrm{O}$ & 95.8 & 0.47 & 1.86 & - \\
\hline CM2 & $40 \% \mathrm{CaSO}_{4}+60 \% \mathrm{CaSO}_{4} \cdot 0.5 \mathrm{H}_{2} \mathrm{O}$ & 95.9 & 0.93 & 1.40 & - \\
\hline CM3 & $60 \% \mathrm{CaSO}_{4}+40 \% \mathrm{CaSO}_{4} \cdot 0.5 \mathrm{H}_{2} \mathrm{O}$ & 95.9 & 1.40 & 0.93 & - \\
\hline CM4 & $80 \% \mathrm{CaSO}_{4}+20 \% \mathrm{CaSO}_{4} \cdot 0.5 \mathrm{H}_{2} \mathrm{O}$ & 96.0 & 1.86 & 0.47 & - \\
\hline
\end{tabular}

Introduction of various forms of calcium sulphates with different dissolution rates to the clinker as the setting regulator, (Table 3 ) and their various quantity aimed at differentiaion of sulphate ions quantity in the solution at the initial stage of cement hydration. 
Table 3. Concentration of $\mathrm{SO}_{4}{ }^{2-}$ sulphate ions in water solutions $\mathrm{CaSO}_{4} \cdot 0.5 \mathrm{H}_{2} \mathrm{O}, \mathrm{CaSO}_{4} \cdot 2 \mathrm{H}_{2} \mathrm{O}$ and $\mathrm{CaSO}_{4}$, after a lapse of different dissolution times, [mg/L].

\begin{tabular}{cccc}
\hline \multirow{2}{*}{$\begin{array}{c}\text { Time } \\
{[\text { min] }}\end{array}$} & \multicolumn{3}{c}{ Concentration of $\mathbf{S O}_{4}{ }^{2-}[\mathrm{mg} / \mathrm{L}]$} \\
\cline { 2 - 4 } & $\mathrm{CaSO}_{4} \cdot \mathbf{0 . 5} \mathbf{H}_{\mathbf{2}} \mathbf{O}$ & $\mathrm{CaSO}_{\mathbf{4}} \cdot \mathbf{2} \mathbf{H}_{\mathbf{2}} \mathbf{O}$ & $\mathrm{CaSO}_{4}$ \\
\hline 10 & $1,544.41$ & 700.53 & 559.68 \\
\hline 20 & $1,599.62$ & 1078.20 & 574.91 \\
\hline 30 & $1,777.82$ & 1147.45 & 639.65 \\
\hline 40 & $1,876.31$ & 1221.47 & 898.46 \\
\hline 60 & $1,966.06$ & 1268.98 & 945.60 \\
\hline
\end{tabular}

As it is known [40], the quantity of sulphate ions in the solution increases along with the growth of the calcium sulphate dissolution rate. $\mathrm{SO}_{4}{ }^{2-}$ ions, bound in the calcium sulphate hemihydrate, penetrate the solution as first, then ions in the calcium sulphate dihydrate, and at last ions of natural anhydrite. The above correlation is also confirmed by results of testing obtained in this paper (Table 3 ).

Two types of new-generation technical superplasticizers (SP), polyoxyethylene derivatives of carboxylic acids (SP-1 and SP-2) were used for testing. SP-1 and SP-2 superplasticizers were applied as $40 \%$ solutions and constituted $1 \mathrm{wt} \%$ of the cement mass.

\section{Testing Methods}

\subsection{Gel Permeation Chromatography (GPC)}

In order to determine a phase composition of superplasticizer test specimens, they were subject to chromatographic distribution into polymer fractions using a method of gel permeation chromatography (GPC) with the use of GPC chromatograph Watt Technology with RI refraction detector and Down EOS-a multi-angle light scattering detector. THF (tetrahydrofuran) was used as an eluent. The chromatographic distribution of superplasticizers in a form of solutions with concentration 1-2\% was performed on GPC column in temp. $35^{\circ} \mathrm{C}$ at eluent flowrate THF $1 \mathrm{~mL} / \mathrm{min}$ with application of a set of gel columns PSS SDV $1 \cdot 10-6 \mathrm{~A}+2 \cdot 100 \mathrm{~A}$ size $300 \mathrm{~mm} \times 8 \mathrm{~mm}$ (Polymer Standard Service).

\subsection{Fourier Transform Infrared Spectroscopy (FTIR)}

Superplasticizers testing by means of IR absorption spectroscopy was conducted using a FTIR spectrometer-PU 9804 model of Philips Analytical (UK), while keeping constant resolution of spectrum equal to $2 \mathrm{~cm}^{-1}$ after twenty scans of each $\mathrm{KBr}$ pellet containing the specimen tested. Recording was performed in a full spectrum range $4000-400 \mathrm{~cm}^{-1}$ using EAGLE v.4.31 computer software.

To determine the content of hydrophobic aliphatic groups: $\mathrm{CH}, \mathrm{CH}_{2}$, ester groups: $\mathrm{O}=\mathrm{C}-\mathrm{O}-\mathrm{CH}_{2}$ and hydrophilic polyoxyethylene groups: $\mathrm{O}-\mathrm{CH}_{2} \mathrm{CH}_{2}$, IR absorption spectra (FTIR) were made for superplasticizers in a solid state. Spectra were standardized to the equal content of specimens in the spectrum beam by means of aliphatic group band, i.e., $2887 \mathrm{~cm}^{-1} \mathrm{STRCH}, \mathrm{CH}_{2}$.

\subsection{Rheological Testing}

Rheological measurements of pastes were conducted using Viscotester VT550 rotational HAAKE viscometer, Karlsruhe, Germany with concentric cylinders. The plastic viscosity of pastes was determined based on the flow curve set for shear rates going up and down within the range from 0 to $150 \mathrm{~s}^{-1}$. The yield stress and plastic viscosity values were calculated based on a Bingham model. Measurements were conducted for cement pastes containing superplasticizer in amount of $1 \%$ by mass, while keeping the equal water-to-solid phase ratio $(w / s)$ equal to 0.39 and the constant temperature $21^{\circ} \mathrm{C}$. 


\subsection{Hydration Heat Testing}

A microcalorimeter of JAF manufactured by Wexham Developments, Reading, UK was used to test hydration heat of cements. Tests were conducted on test specimens of the cement paste with addition of $1 \%$ by mass of superplasticizer during $48 \mathrm{~h}$, while keeping a constant $\mathrm{w} / \mathrm{c}$ ratio equal to 0.4 and the constant temperature $21^{\circ} \mathrm{C}$.

\section{Results of Testing and their Interpretation}

\subsection{Test Results of Superplasticizers Structure}

Based on GPC tests (Figure 1), presence of two different polymer fractions was found in SP-2 specimen, whereas in SP-1 specimen the additional third fraction was found. Polymer fractions 1 originated from pure superplasticizers, while fractions 2 and 3 from a part of unreacted poly(ethylene glycols) (PEG) used in the synthesis of superplasticizers.

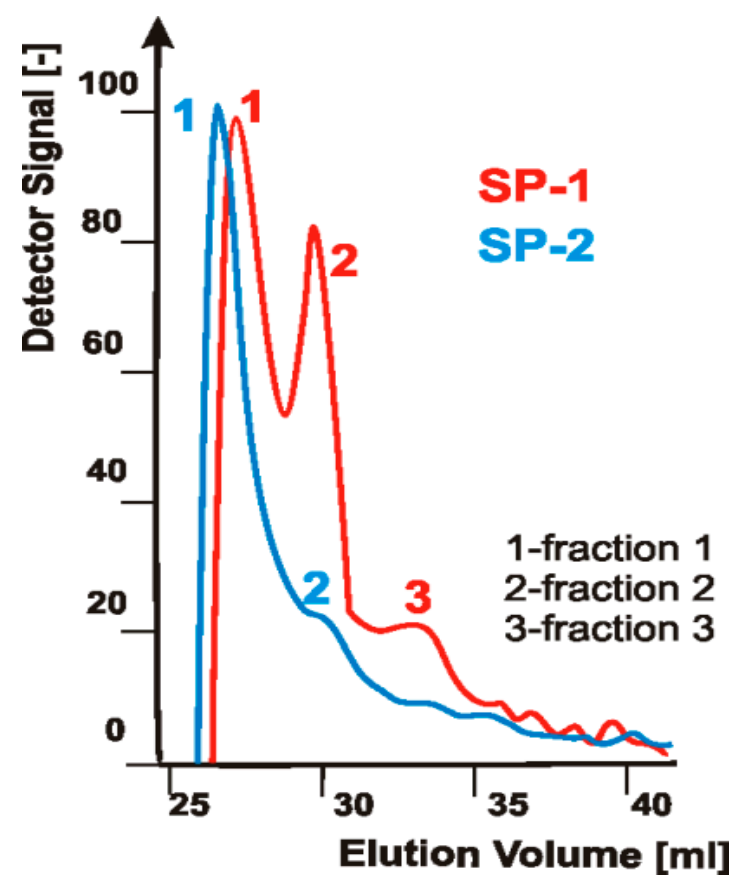

Figure 1. GPC chromatograms of superplasticizers specimens (SP-1, SP-2), [based on results published in [41]].

Individual polymer fractions present in superplasticizers specimens differed with each other with a molar mass and polydispersity (MWD $=$ Mw $/$ ML molecular weight distribution (Figure 2).

Molecular mass weight-average (Mw) of SP-1 superplasticizer was ca. 12,000 g/mol, and as shown by GPC testing, it was heavily contaminated with residual poly(ethylene glycols), content of which was $48.3 \%$. Whereas, SP-2 specimen had higher molecular mass weight-average equal to ca. 14,000 g/mol and much lower content of free poly(ethylene glycols), i.e., $14-18 \%$. Therefore, it contained more pure polymer of the superplasticizer (ca. $82 \%$ ), which for SP-1 specimen amounted to $51 \%$. 


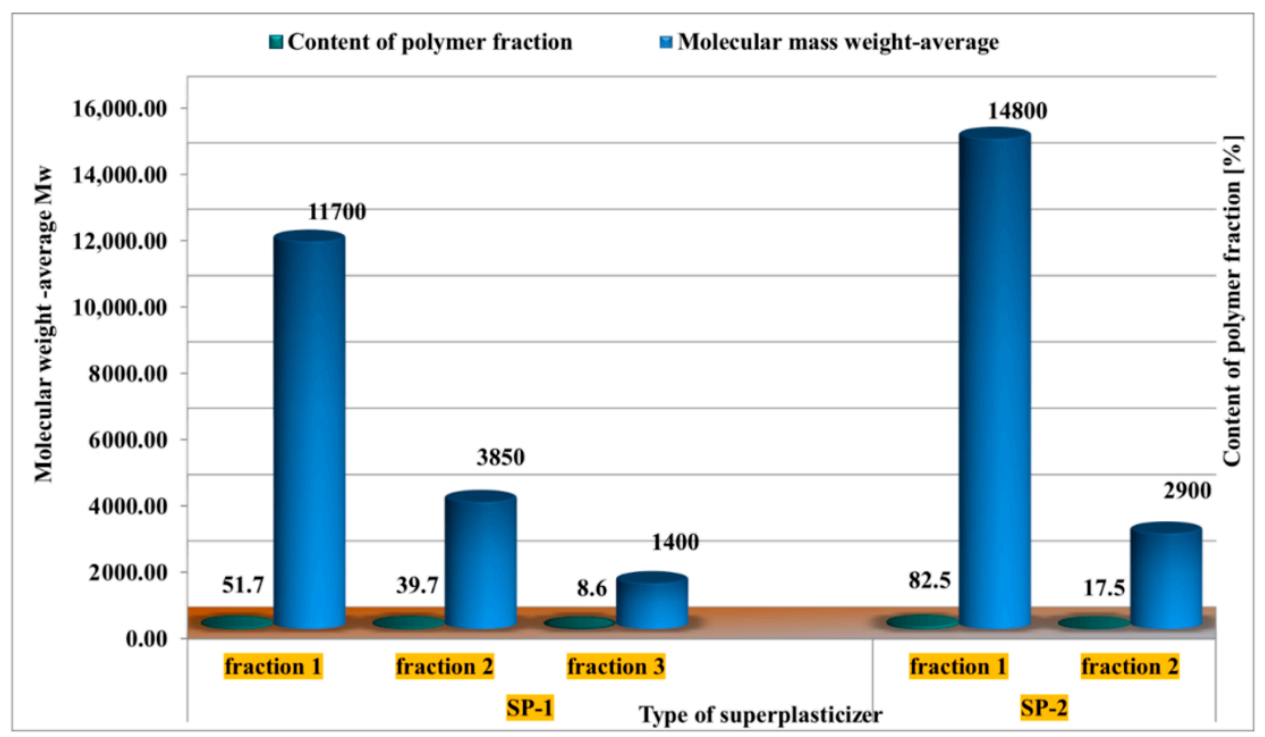

Figure 2. Results of the GPC chromatographic analysis of superplasticizer polymer fractions (SP-1, SP-2), [based on results published in [41]].

GPC testing showed that superplasticizers tested were polyoxyethylene derivatives of carboxylic acids. SP-1 specimen originated from esterification of acrylic acid oligomers with a mixture of poly(ethylene glycols) PEG 1500 + PEG 4000. Whereas SP-2 specimen originated from esterification of maleic anhydride oligomers by means of poly(ethylene glycol) PEG 3000. Approximate structures of superplasticizers are presented in Figure 3.
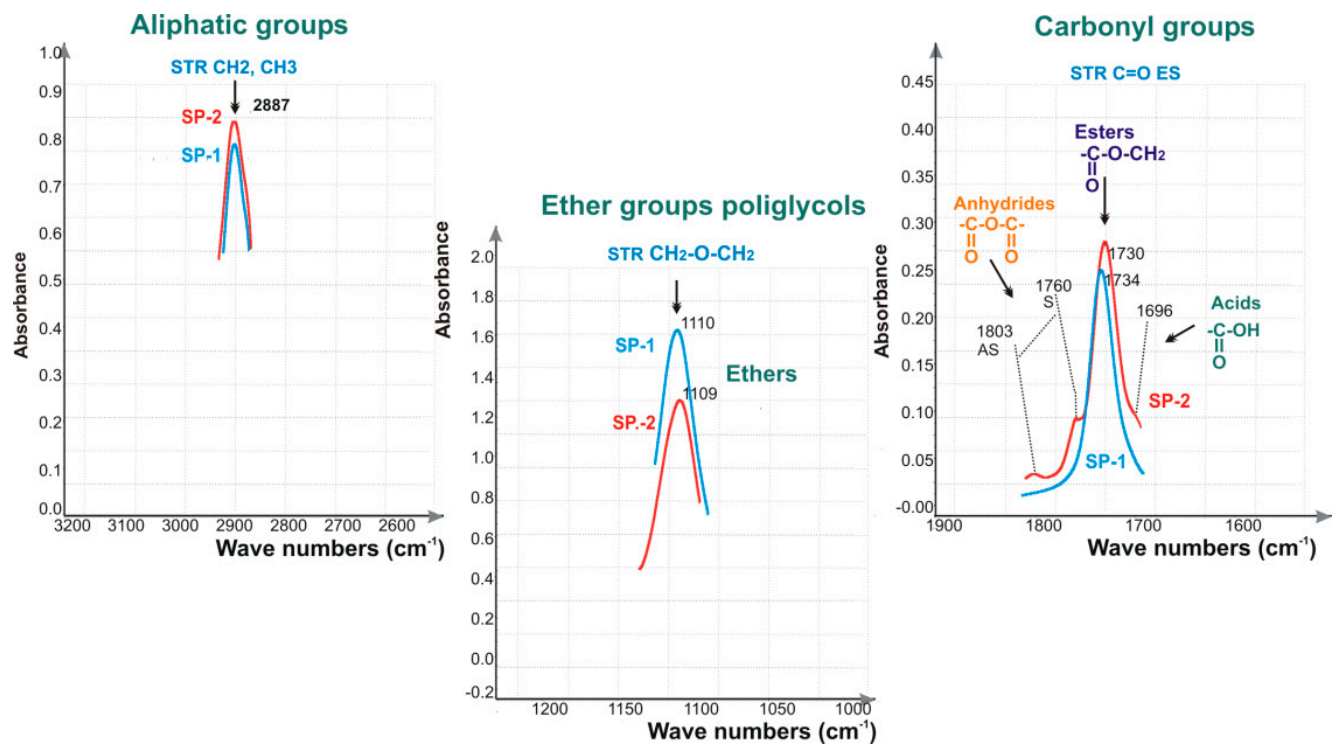

Figure 3. Selected function groups: Aliphatic, ether and carbonyl groups identified by means of IR testing), (based on results published in [41]).

Based on FTIR spectra, presence of characteristic function groups was found in superplasticizers in selected spectrum bands for aliphatic groups frequency $\left(3200-2500 \mathrm{~cm}^{-1}\right)$, carbonyl groups (1900-1500 $\mathrm{cm}^{-1}$ ) and ether groups (1250-950 $\mathrm{cm}^{-1}$ ) (Figure 4). 


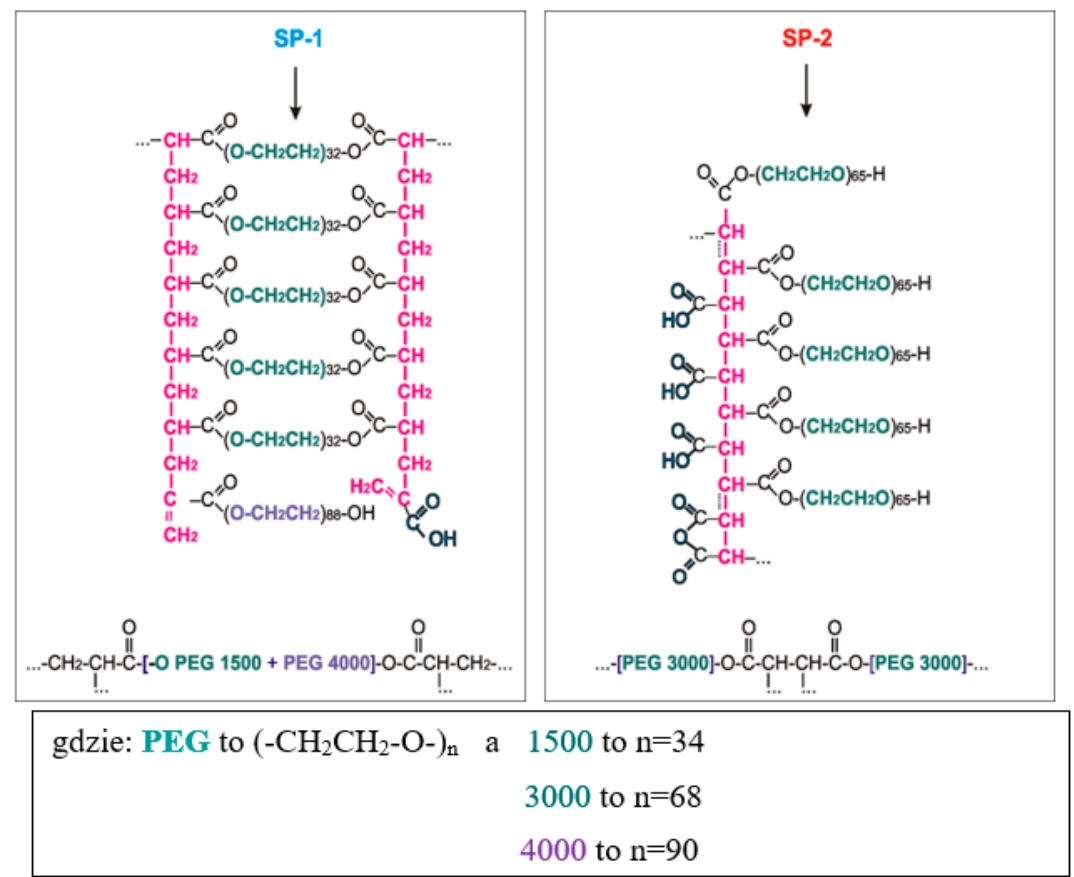

Figure 4. Approximate chemical structures of superplasticizers: ladder-shaped (SP-1) and combshaped (SP-2) determined based on mathematical calculation of molar masses.

FTIR spectra characteristic for carbonyl groups $1500-1900 \mathrm{~cm}^{-1}$ for SP-2 specimen, apart from esters (1730-1734 $\mathrm{cm}^{-1}$ ), certain amounts of free carbonyl acids were found $\left(1696 \mathrm{~cm}^{-1}\right)$, as well as the maleic anhydride (doublet $\left.1803,1760 \mathrm{~cm}^{-1}\right)$.

Absorbance values of bands specific for hydrophobic aliphatic groups read from FTIR spectra (Figure 4) with the wave number $2887 \mathrm{~cm}^{-1} \mathrm{STRCH}, \mathrm{CH}_{2}$ and ester groups with the wave number 1730-1734 $\mathrm{cm}^{-1} \mathrm{STRC}=\mathrm{OES}$, and for hydrophilic oxyethylene groups $1109-1112 \mathrm{~cm}^{-1} \mathrm{STRCH}_{2}-\mathrm{O}-\mathrm{CH}_{2}$ ET for the poly (ethylene glycol) chains of free PEGs, as well as for the ester groups present in superplasticizers are presented in Figure 5.

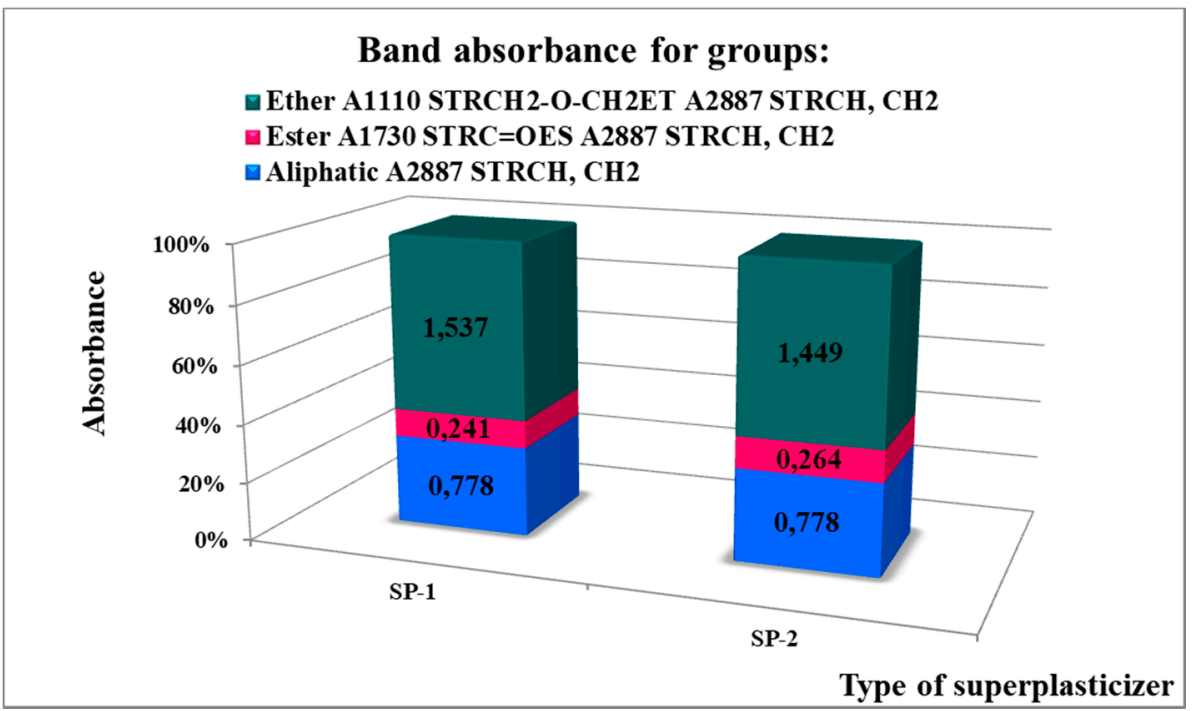

Figure 5. Results of FTIR spectral analysis of superplasticizer samples (based on results published in [41]).

Based on polymer fraction weight content determined with the GPC method for SP superplasticizer (fraction 1) and free PEG (fraction 2, and possibly fraction 3) in specimens 
tested, distribution (content) of ether groups absorbance in both polymers was defined (Table 4).

Table 4. Hydrophilicity and distribution of ether groups between SP polymer and free PEGs developed based on [41].

\begin{tabular}{ccccccc}
\hline \multirow{2}{*}{ SP Specimen } & \multicolumn{2}{c}{ SP Hydrophilicity } & \multicolumn{2}{c}{ Mass Fraction of Polymer } & \multicolumn{2}{c}{ Absorbance of Ether Band } \\
\cline { 2 - 6 } & $\mathbf{A}_{\mathrm{ET}}{ }^{\mathbf{1 1 1 0}} / \mathbf{A}_{\mathrm{ES}} \mathbf{1 7 3 0}^{\text {1730 }}$ & $\begin{array}{c}\text { in SP } \\
\text { (Fraction 1) }\end{array}$ & $\begin{array}{c}\text { in PEG } \\
\text { (Fractions 2 and 3) }\end{array}$ & $\begin{array}{c}\text { in SP } \\
\text { (Fraction 1) }\end{array}$ & $\begin{array}{c}\text { in PEG } \\
\text { (Fractions 2 and 3) }\end{array}$ \\
\hline SP-1 & 3.30 & 0.517 & 0.483 & 0.793 & 0.742 \\
\hline SP-2 & 4.53 & 0.825 & 0.175 & 1.195 & 0.254 \\
\hline
\end{tabular}

Based on FTIR test results, hydrophilicity of superplasticizers was calculated (Table 4) following a definition given by Grzeszczyk and Sudoła [42].

It was found that SP-2 superplasticizer had the higher hydrophilicity (a ratio of absorbance of hydrophilic ether groups $\mathrm{AET}^{1110}$ to hydrophobic ester groups $\mathrm{AES}^{1730}$ ) equal to $\mathrm{A}_{\mathrm{ET}}{ }^{1110} / \mathrm{A}_{\mathrm{ES}}{ }^{1730}=4.53$, compared to hydrophilicity of SP-1 superplasticizer, i.e., $\mathrm{A}_{\mathrm{ET}}{ }^{1110} / \mathrm{A}_{\mathrm{ES}}{ }^{1730}=3.30$, which suggest high probability of SP-2 better efficiency in hydrophilic solvents.

\subsection{Results of Rheological Testing}

Flow curves of cement-based pastes, containing calcium sulphates $\left(\mathrm{CaSO}_{4}, \mathrm{CaSO}_{4} \cdot 2 \mathrm{H}_{2} \mathrm{O}\right.$, $\left.\mathrm{CaSO}_{4} \cdot 0.5 \mathrm{H}_{2} \mathrm{O}\right)$ as the setting time regulator, without and with SP-1 and SP-2 superplasticizers after 10 and 60 min of hydration are presented in Figures 6-11.

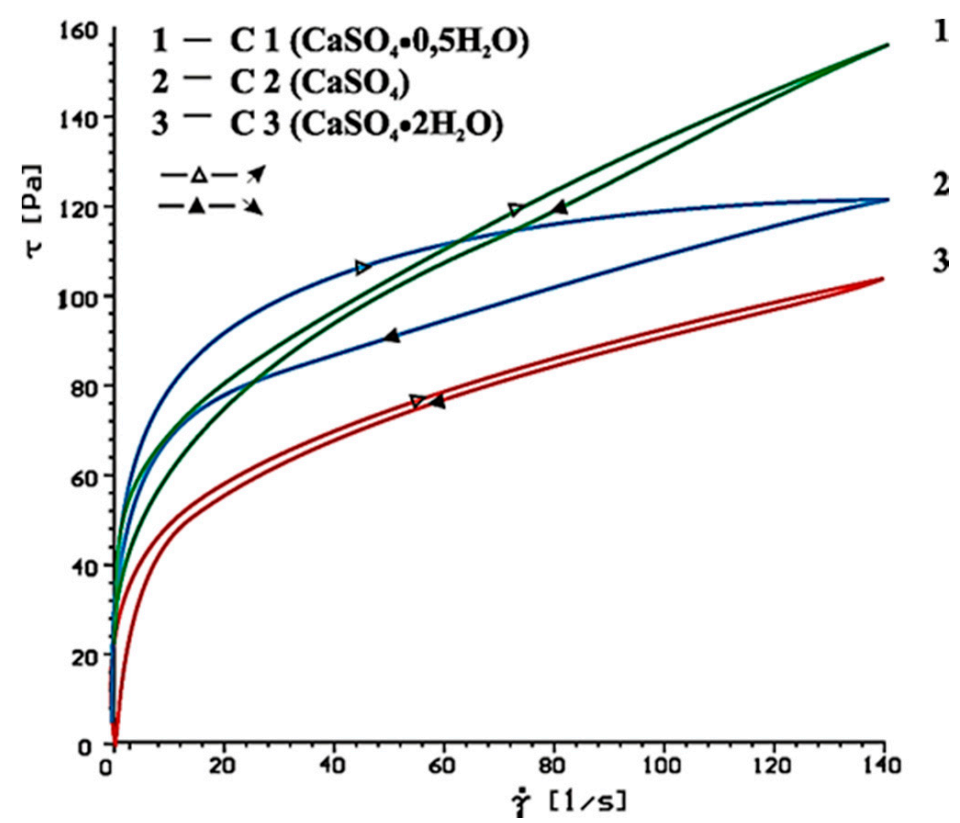

Figure 6. Flow curves of cement pastes with addition of $\mathrm{CaSO}_{4} \cdot 0.5 \mathrm{H}_{2} \mathrm{O}, \mathrm{CaSO}_{4}, \mathrm{CaSO}_{4} \cdot 2 \mathrm{H}_{2} \mathrm{O}$, after $10 \mathrm{~min}$. 


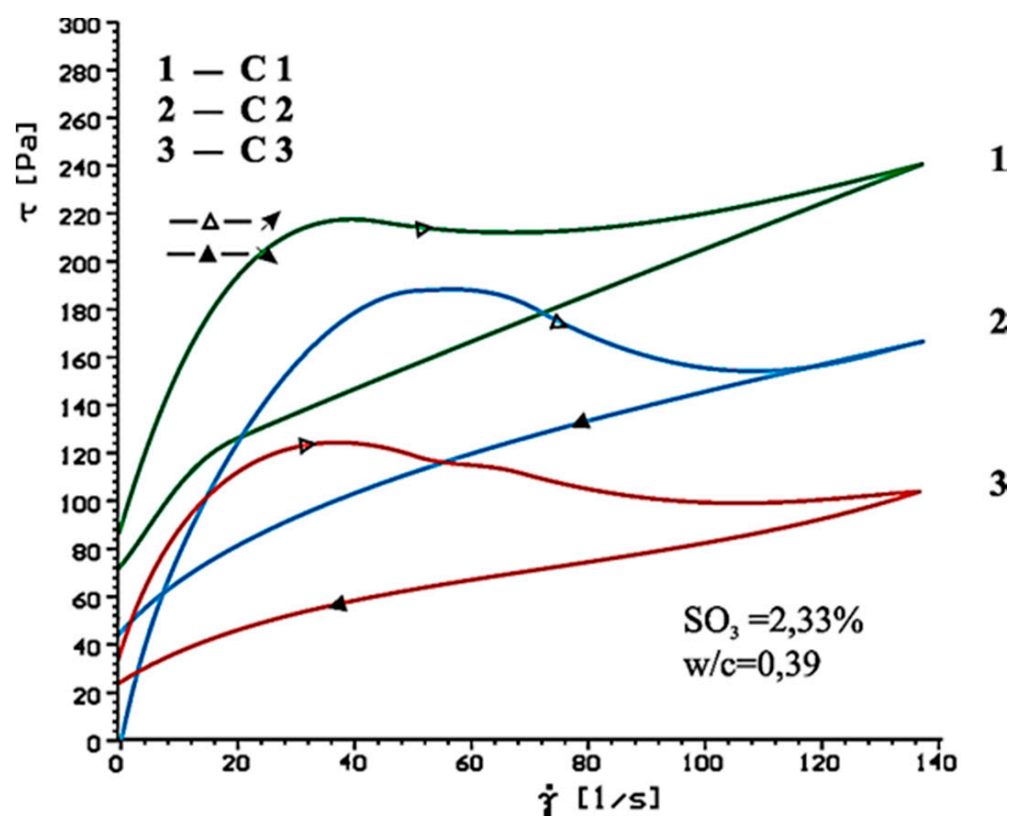

Figure 7. Flow curves of cement pastes with addition of $\mathrm{CaSO}_{4} \cdot 0.5 \mathrm{H}_{2} \mathrm{O}, \mathrm{CaSO}_{4}, \mathrm{CaSO}_{4} \cdot 2 \mathrm{H}_{2} \mathrm{O}$, after $60 \mathrm{~min}$.

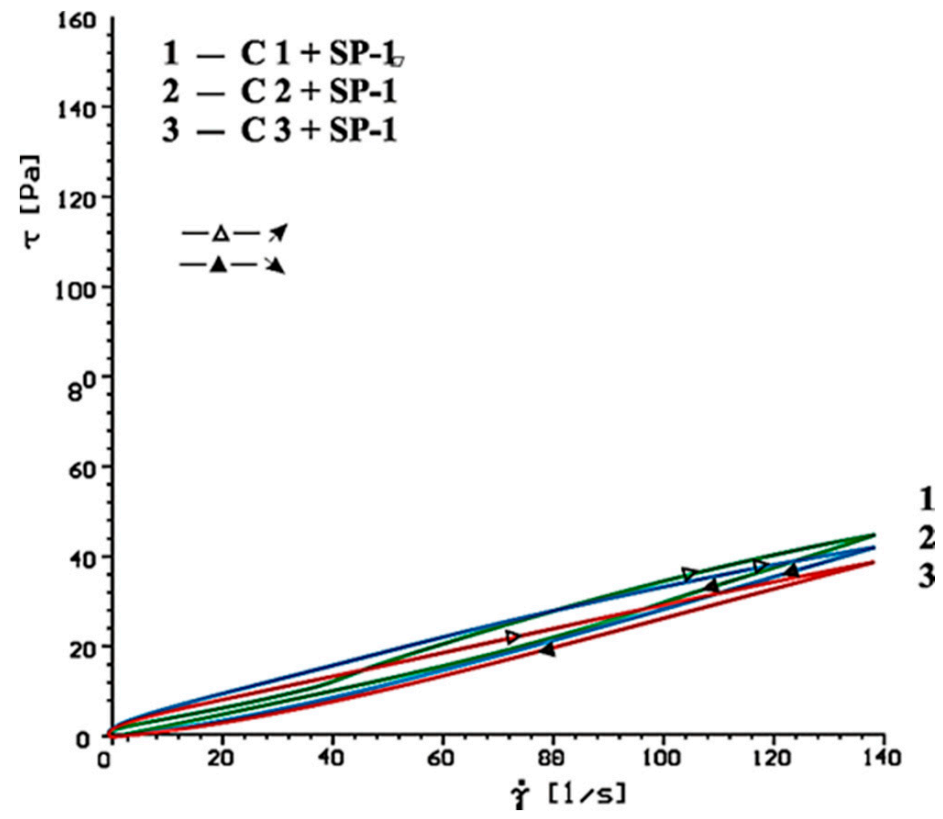

Figure 8. Flow curves of cement pastes with addition of $\mathrm{CaSO}_{4} \cdot 0.5 \mathrm{H}_{2} \mathrm{O}, \mathrm{CaSO}_{4}, \mathrm{CaSO}_{4} \cdot 2 \mathrm{H}_{2} \mathrm{O}$ in presence of SP-1 superplasticizer, after $10 \mathrm{~min}$. 


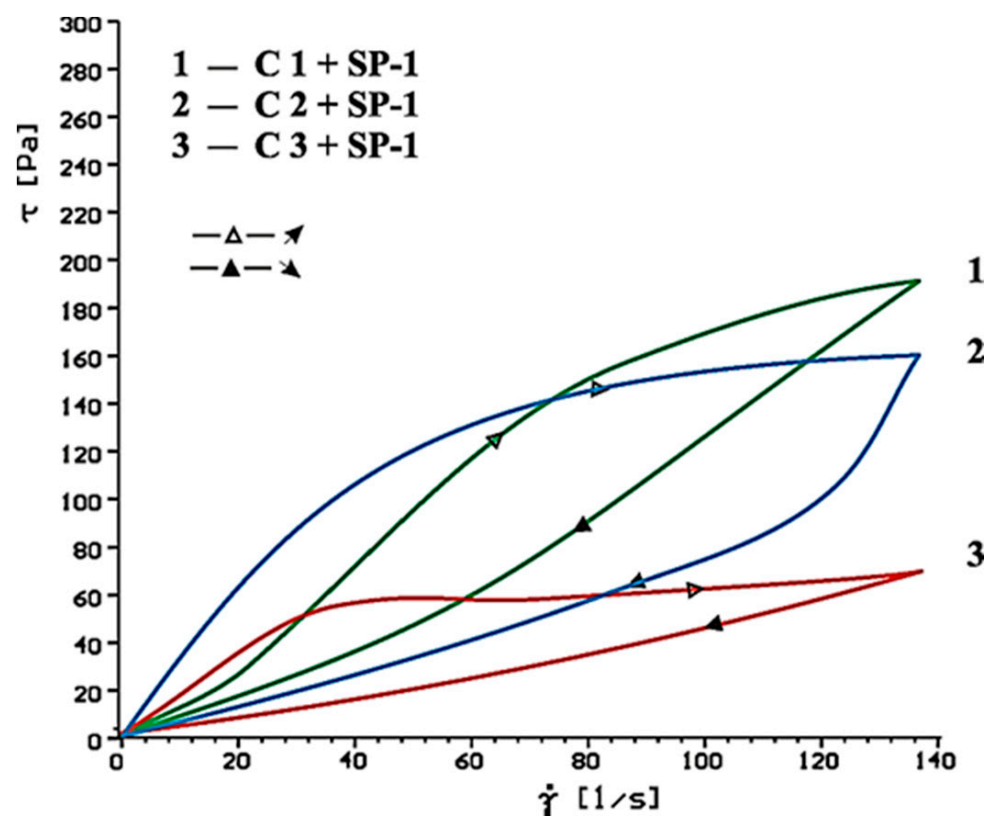

Figure 9. Flow curves of cement pastes with addition of $\mathrm{CaSO}_{4} \cdot 0.5 \mathrm{H}_{2} \mathrm{O}, \mathrm{CaSO}_{4}, \mathrm{CaSO}_{4} \cdot 2 \mathrm{H}_{2} \mathrm{O}$ in presence of SP-1 superplasticizer, after $60 \mathrm{~min}$.

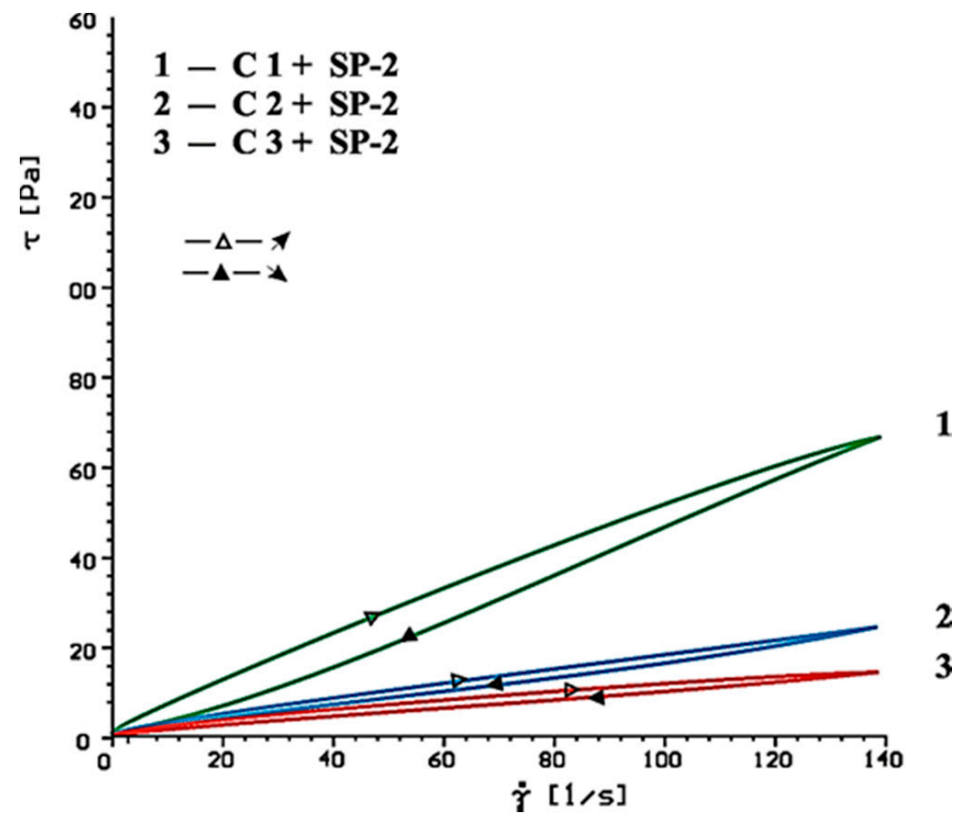

Figure 10. Flow curves of cement pastes with addition of $\mathrm{CaSO}_{4} \cdot 0.5 \mathrm{H}_{2} \mathrm{O}, \mathrm{CaSO}_{4}, \mathrm{CaSO}_{4} \cdot 2 \mathrm{H}_{2} \mathrm{O}$ in presence of SP-2 superplasticizer, after $10 \mathrm{~min}$. 


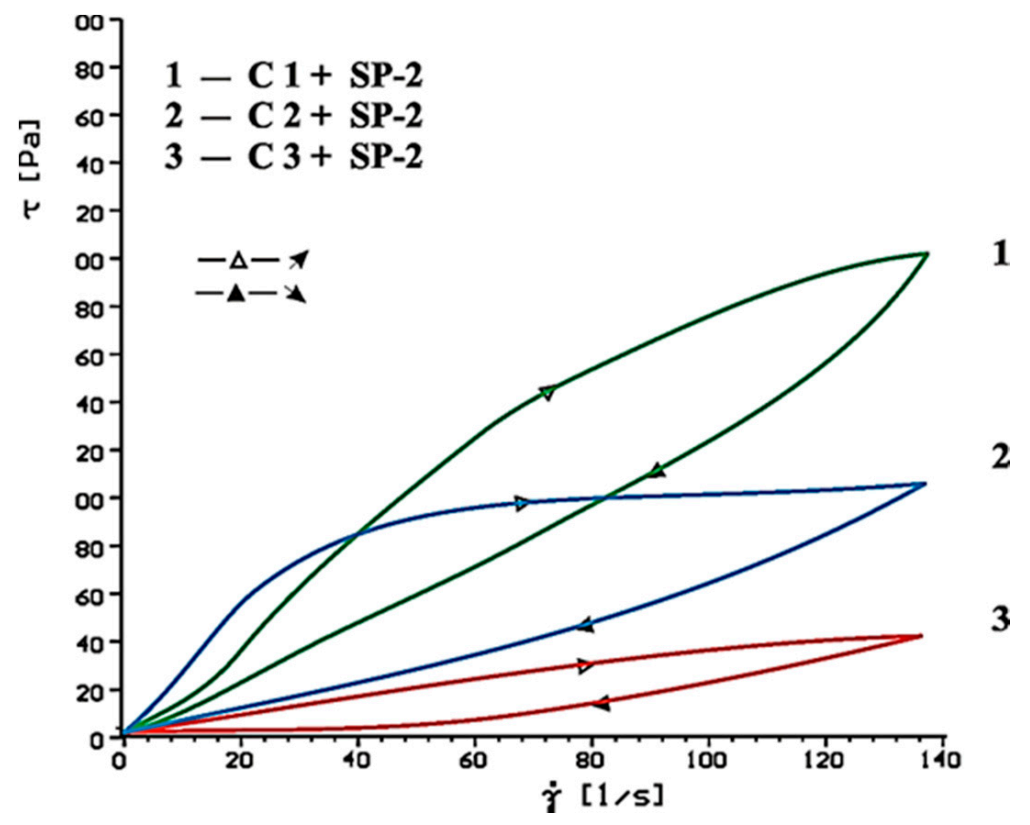

Figure 11. Flow curves of cement pastes with addition of $\mathrm{CaSO}_{4} \cdot 0.5 \mathrm{H}_{2} \mathrm{O}, \mathrm{CaSO}_{4}, \mathrm{CaSO}_{4} \cdot 2 \mathrm{H}_{2} \mathrm{O}$ in presence of SP-2 superplasticizer, after $60 \mathrm{~min}$.

The Table 5 shows yield stress and plastic viscosity values for cement pastes tested.

The addition of various forms of calcium sulphate (with various dissolution rates) to the cement as the setting time regulator, aimed at differentiation of sulphate ions concentration in the solution at the initial stage of cement hydration.

Calcium sulphates used had different dissolution rates (Table 3), thus, accessibility of sulphate ions in the paste was diverse. The quantity of sulphate ions in the solution grows along with the increase of the dissolution rate of individual types of the calcium sulphate [43]. $\mathrm{SO}_{4}{ }^{2-}$ ions, originating from the calcium sulphate hemihydrate, penetrate the solution as first, then ions from the calcium sulphate anhydrite, and at last ions of calcium sulphate dihydrate.

Table 5. Yield stress $\tau_{0}[\mathrm{~Pa}]$ and plastic viscosity $\eta_{\mathrm{pl}}[\mathrm{Pa} \cdot \mathrm{s}]$ values of cement pastes with addition of calcium sulphates in presence of the superplasticizer after 10 and $60 \mathrm{~min}$.

\begin{tabular}{|c|c|c|c|c|c|}
\hline \multirow{2}{*}{ Type of Paste } & \multirow{2}{*}{$\begin{array}{l}\text { Time } \\
\text { [min] }\end{array}$} & \multicolumn{2}{|c|}{ Without Superplasticizer } & \multirow{2}{*}{$\frac{1 \% \text { SP-1 }}{\eta_{\mathrm{pl}}[\text { Pas] }}$} & \multirow{2}{*}{$\frac{1 \% \mathrm{SP}-2}{\eta_{\mathrm{pl}}[\mathrm{Pas}]}$} \\
\hline & & $\tau_{0}[\mathrm{~Pa}]$ & $\eta_{\mathrm{pl}}[$ Pas $]$ & & \\
\hline \multirow{2}{*}{$\mathrm{C} 1\left(\right.$ clinker $\left.+\mathrm{CaSO}_{4} \cdot 0.5 \mathrm{H}_{2} \mathrm{O}\right)$} & 10 & 69.9 & 0.63 & 0.38 & 0.51 \\
\hline & 60 & 105.9 & 0.94 & 1.49 & 1.50 \\
\hline \multirow{2}{*}{$\mathrm{C} 2\left(\right.$ clinker $\left.+\mathrm{CaSO}_{4}\right)$} & 10 & 74.6 & 0.36 & 0.31 & 0.16 \\
\hline & 60 & 68.2 & 0.67 & 0.80 & 0.74 \\
\hline \multirow{2}{*}{$\mathrm{C} 3\left(\right.$ clinker $\left.+\mathrm{CaSO}_{4} \cdot 2 \mathrm{H}_{2} \mathrm{O}\right)$} & 10 & 54.9 & 0.32 & 0.30 & 0.10 \\
\hline & 60 & 52.9 & 0.43 & 0.49 & 0.33 \\
\hline
\end{tabular}

In the analysis of results the following identification was introduced for cements containing various forms of calcium sulphate: $\mathrm{C} 1$ contains $\mathrm{CaSO}_{4} \cdot 0.5 \mathrm{H}_{2} \mathrm{O}, \mathrm{C} 2-\mathrm{CaSO}_{4}$ and C3- $\mathrm{CaSO}_{4} \cdot 2 \mathrm{H}_{2} \mathrm{O}$ (Table 3). The total quantity of sulphates introduced into cements was the same and it amounted to $2.33 \% \mathrm{SO}_{3}$.

Flow curves of cementitious pastes without and with $1 \%$ by mass content of SP1 acrylic superplasticizer or SP-2 maleic superplasticizer after 10 and 60 min of hydration are presented in Figures 6-11, Table 5 shows yield stress and plastic viscosity values for pastes tested. 
As could be expected, the highest yield stress and plastic viscosity value was demonstrated by a cementitious paste (C1) with a gypsum hemihydrate. The plastic viscosity of this paste was twofold higher than the plastic viscosity of the paste containing $\mathrm{CaSO}_{4}(\mathrm{C} 2)$ and $\mathrm{CaSO}_{4} \cdot 2 \mathrm{H}_{2} \mathrm{O}(\mathrm{C} 3$ ). It is caused by false binding (formation of gypsum crystals) in case of solution supersaturation in the cement paste is compared to gypsum [3].

Much lower value of rheological parameters for C2 and C3 pastes is a result of delayed hydration process of $\mathrm{C}_{3} \mathrm{~A}$ phase with addition of gypsum dihydrate and anhydride. However, cementitious pastes containing anhydrite as the setting time regulator showed higher yield stress and plastic viscosity than pastes with calcium sulphate dihydrate. The following relation was observed by Bensted [40] and Bundyra-Oracz [44].

Based on obtained results of rheological tests of pastes containing different forms of calcium sulphates, better efficiency was found for SP-2 superplasticizer compared to SP-1. Undoubtedly it results from different chemical and molecular structure of the superplasticizers used, particularly amount of hydrophilic groups determined by a coefficient of hydrophilicity.

The SP-2 superplasticizer that has a higher hydrophilicity coefficient $\left(\mathrm{AET}^{1110} / \mathrm{AES}^{1730}\right.$ $=4.53$ ), built from shorter backbone chains, containing more $\mathrm{COO}^{-}$carboxylate groups, and very long hydrophilic polyether side chains ( $\mathrm{n}=68$ oxyethylene mers in diols, PGE 3000, Figure 3), shows better efficiency compared to SP-1 superplasticizer with a lower hydrophilicity coefficient $\left(\mathrm{AET}^{1110} / \mathrm{AES}^{1730}=3.30\right)$. That last one contains a longer backbonemethacrylic chain (with a smaller amount of carboxylate groups), to which shorter side chains are connected $(n=34$ i $n=90$ oxyethylene mers in chains of diols, PGE 1500 and PGE 4000, Figure 2).

The above conclusion can be generalized, i.e., the higher efficiency of the SP-2 superplasticizer results from long side chains and the $\mathrm{COO}^{-}$groups (confirmed by the FTIR results) that make the cement flocculation difficult [14,17].

In case of higher concentration of $\mathrm{SO}_{4}{ }^{2-}$ ions after the shorter hydration time in $\mathrm{C} 1$ cement paste with addition of $\mathrm{CaSO}_{4} \cdot 0.5 \mathrm{H}_{2} \mathrm{O}$, with the highest dissolution rate (Table 3 ), efficiency of SP-2 superplasticizer is lower $\left(\eta_{\mathrm{pl}}=0.51 \mathrm{~Pa} \cdot \mathrm{s}\right)$ than SP-1 superplasticizer $\left(\eta_{\mathrm{pl}}=0.38 \mathrm{~Pa} \cdot \mathrm{s}\right.$, Table 5). Under these conditions, the maleic superplasticizer (SP-2) does not inhibit formation of gypsum dihydrate in the cement paste.

In this case, the lower efficiency of the maleic superplasticizer (SP-2) (higher viscosity of the paste) may be explained by an impact of high sulphate ions concentration in the paste on impediment of $\mathrm{COO}^{-}$carboxylate group adsorption on grains of $\mathrm{C}_{3} \mathrm{~A}$ phase. The effect of sulphate ions that impede adsorption of carboxylate admixtures on cement grains, along with their increased content in the paste, was also demonstrated by Nakajima and Yamada [37] Aitcin [45], and Zingg [46].

In case of SP-1 superplasticizer, due to a very small amount of $\mathrm{COO}^{-}$groups, adsorption may occur through partial negative charges present in the backbone chain, formed in result of polarity of bonds in ester groups [47]. Polyether side chains, including in the superplasticizer, connected with the backbone chain simultaneously by two ester bonds, increase the distance between cement grains, and deflocculating them effectively. To some extent, it may explain the higher efficiency of the acrylic superplasticizer with the increased amount of sulphate ions.

It is worth to emphasize that with addition of SP-2 superplasticizer to the cement paste, in the initial period (10 min.), the influence of sulphate ions concentration in the paste (type of sulphate) is observed on its efficiency, unlike SP-1 superplasticizer, where no such effect is observed (Figures 8 and 10). It is confirmed by the results of rheological testing of $\mathrm{C} 1, \mathrm{C} 2$ and $\mathrm{C} 3$ cement pastes that show minimum differences in plastic viscosity of pastes containing SP-1 superplasticizer. It proves a lower impact of sulphate ions content in the solution on paste fluidity by the acrylic superplasticizer. After $60 \mathrm{~min}$, in both cases (SP-1 and SP-2), the impact of sulphate ions concentration on the increase of paste viscosity (higher calcium sulphate dissolution rate increases the paste viscosity) is visible, 
Figures 9 and 11, Table 5). The highest plastic viscosity of the paste containing $\mathrm{CaSO}_{4} \cdot 0.5 \mathrm{H}_{2} \mathrm{O}$ is most likely caused by a false bond.

Effect of sulphate ions $\left(\mathrm{SO}_{4}{ }^{2-}\right)$ on efficiency of SP-1 superplasticizer (less sensitive to sulphate content) was tested by introducing to cements C1, C2 and C3 (Table 2) the potassium sulphate with a significant dissolution rate, in the amount of $1 \%$ by mass (Figure 12).

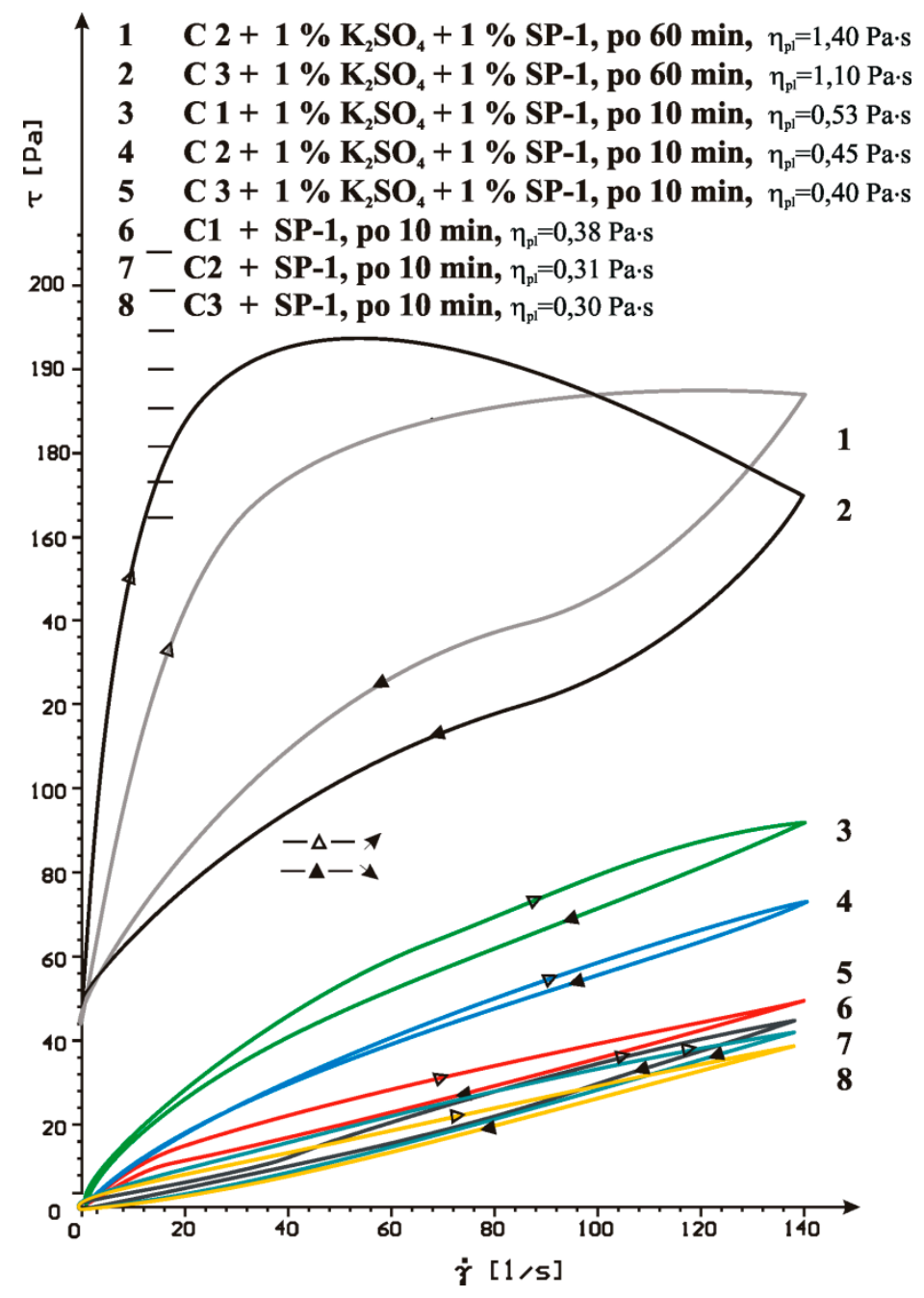

Figure 12. Flow curves of pastes of $\mathrm{C} 1, \mathrm{C} 2$ and $\mathrm{C} 3$ cements containing $\mathrm{K}_{2} \mathrm{SO}_{4}$ in presence of SP-1 in $1 \%$ by mass, after 10 and $60 \mathrm{~min}$.

The results of rheological testing showed that the introduction of the potassium sulphate caused a loss of fluidity in all pastes, i.e., C1, C2 and C3 already after $10 \mathrm{~min}$. Whereas, after $60 \mathrm{~min}$, the increase of rheological parameters was so big that the measurement in case of $\mathrm{C} 1$ cement paste containing gypsum hemihydrate was impossible. Flow curves of $\mathrm{C} 2$ and $\mathrm{C} 3$ cement pastes containing $\mathrm{K}_{2} \mathrm{SO}_{4}$ showed a clearly marked thixotropy with a large surface area of the hysteresis loop (Figure 12).

The significant increase of the yield stress and plastic viscosity of pastes observed may be caused by formation of a syngenite, which is reported by Kurdowski [48]. The increase of rheological parameters in pastes with $\mathrm{K}_{2} \mathrm{SO}_{4}$ was also observed by Andersen et al. [49].

The introduction of the potassium sulphate $\left(\mathrm{K}_{2} \mathrm{SO}_{4}\right)$ to the paste has affects a significant increase of ionic strength, which in the case of the superplasticizer containing polyoxyethylene chains (PEG), will lead to quick clustering of these side chains and reduction of steric effect (Figure 13) [50,51]. It may also affect the loss of paste fluidity (Figure 12). 


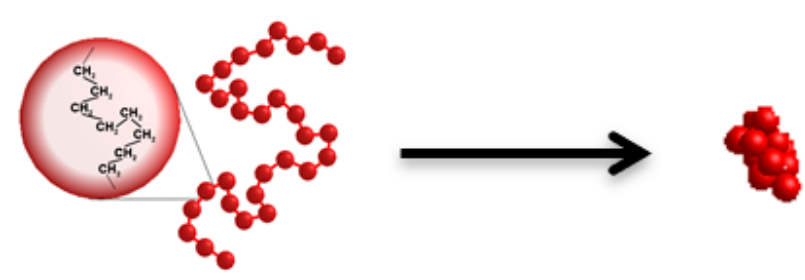

Figure 13. Two states of polymer in the solution: a freely unfolded chain and chain condensed under the stimulus impact-attraction of chain segments based on [52].

Figures 14-19 show flow curves of pastes made from cements (CM1, CM2, CM3 and $\mathrm{CM} 4$ ) containing mixtures of calcium sulphates $\mathrm{CaSO}_{4} \cdot 0.5 \mathrm{H}_{2} \mathrm{O}$ and $\mathrm{CaSO}_{4}$ with, and without, SP-1 and SP-2 superplasticizers in amount of $1 \%$ by mass. The yield stress and plastic viscosity values determined for these pastes containing mixtures of sulphates are given in Table 6.

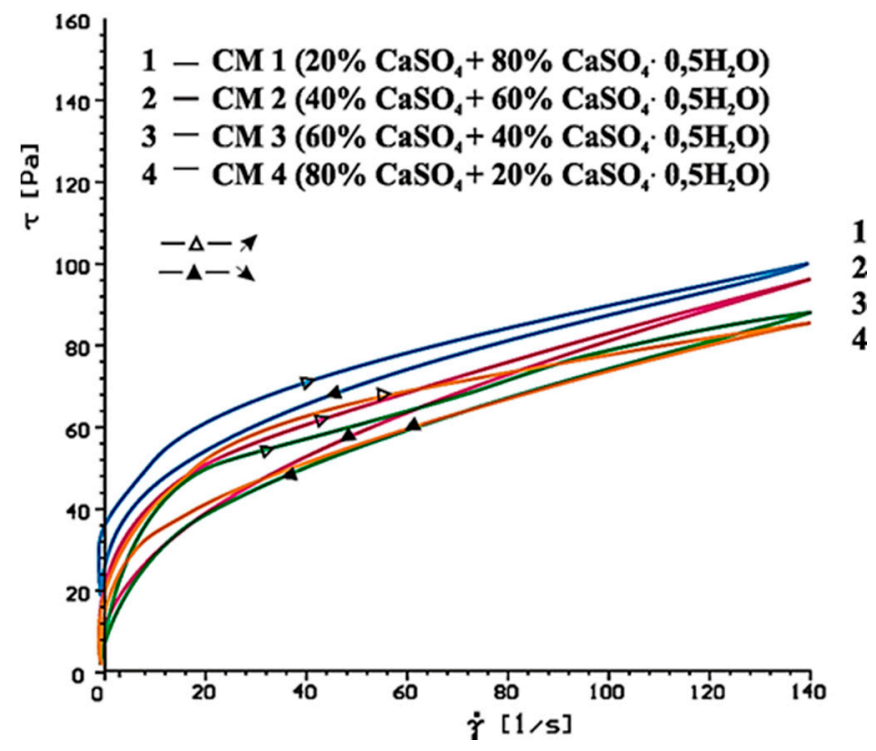

Figure 14. Flow curves of cementitious pastes containing $5 \%$ by mass of $\mathrm{CaSO}_{4} \cdot 0.5 \mathrm{H}_{2} \mathrm{O}$ and $\mathrm{CaSO}_{4}$ in quantity from 20 to $80 \%$ by mass, after $10 \mathrm{~min}$.

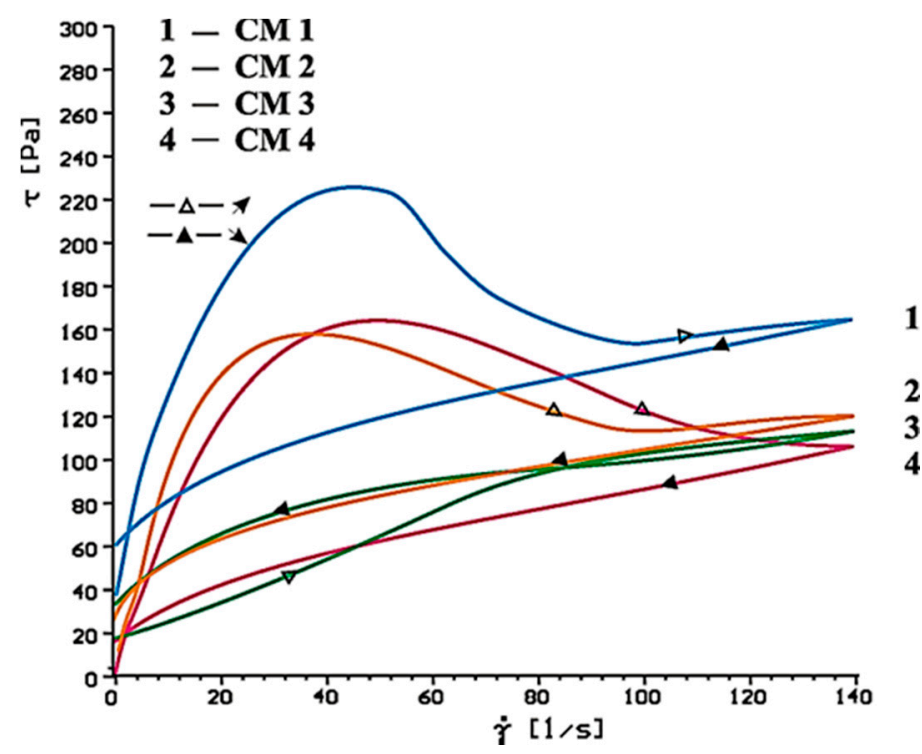

Figure 15. Flow curves of cementitious pastes containing $5 \%$ by mass of $\mathrm{CaSO}_{4} \cdot 0.5 \mathrm{H}_{2} \mathrm{O}$ and $\mathrm{CaSO}_{4}$ in quantity from 20 to $80 \%$ by mass, after $60 \mathrm{~min}$. 


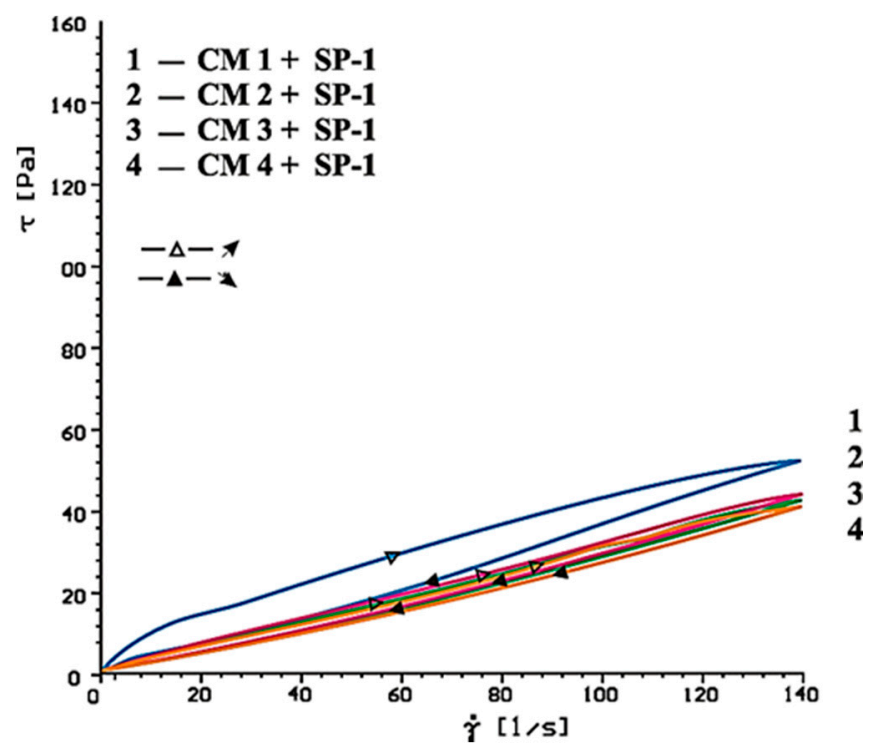

Figure 16. Flow curves of cementitious pastes containing $5 \%$ by mass of $\mathrm{CaSO}_{4} \cdot 0.5 \mathrm{H}_{2} \mathrm{O}$ and $\mathrm{CaSO}_{4}$ in quantity from 20 to $80 \%$ by mass in presence of SP-1 type superplasticizer, $1 \%$ by mass, after $10 \mathrm{~min}$.

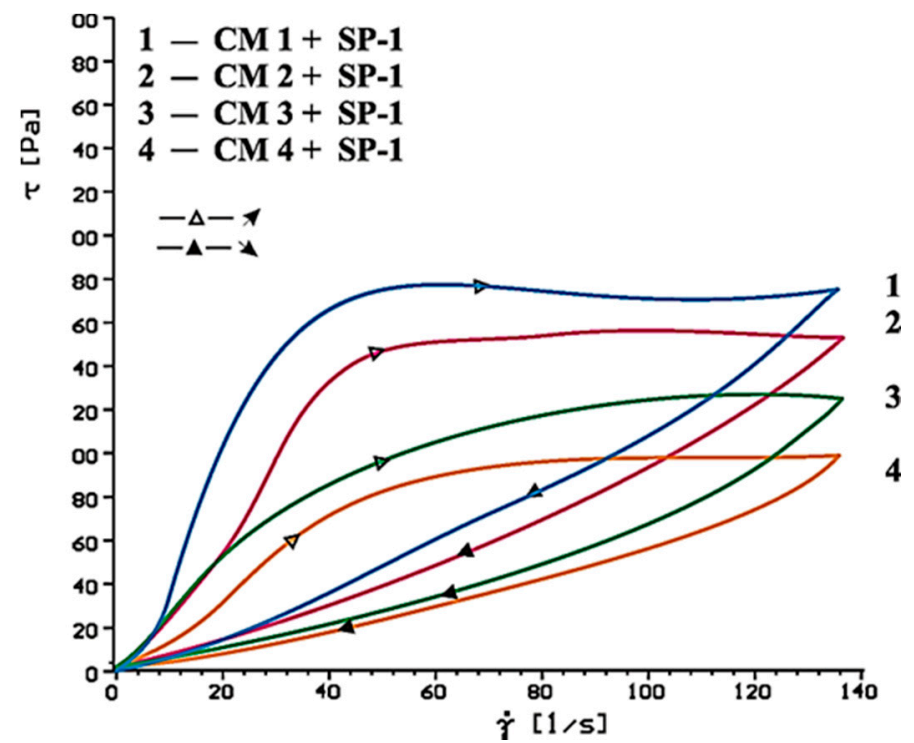

Figure 17. Flow curves of cement pastes containing $5 \%$ by mass of $\mathrm{CaSO}_{4} \cdot 0.5 \mathrm{H}_{2} \mathrm{O}$ and $\mathrm{CaSO}_{4}$ in quantity from 20 to $80 \%$ by mass in presence of SP-1 type superplasticizer, $1 \%$ by mass, after $60 \mathrm{~min}$. 


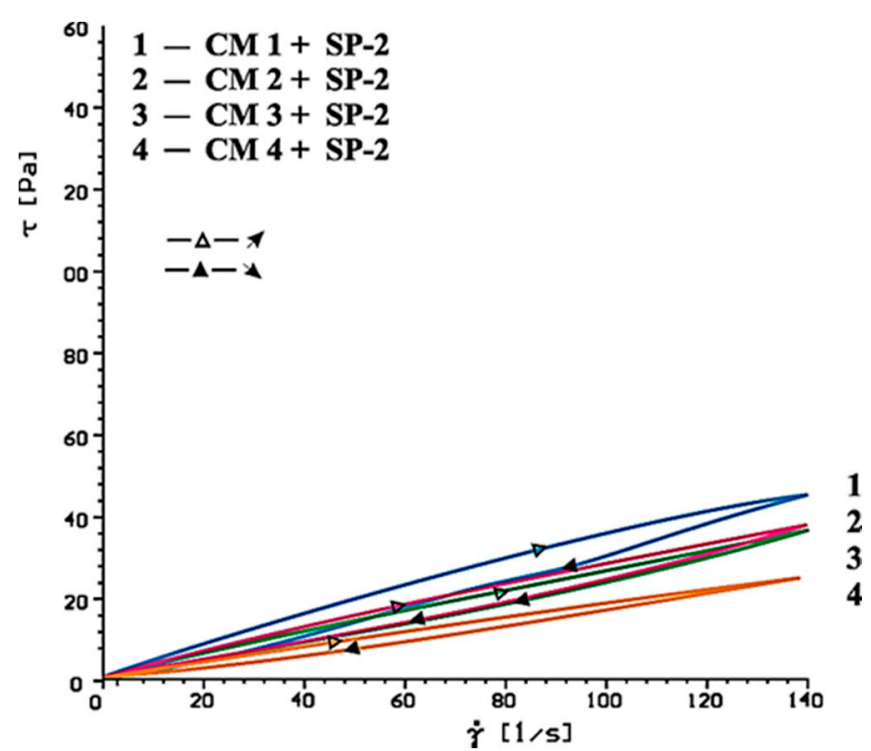

Figure 18. Flow curves of cementitious pastes containing $5 \%$ by mass of $\mathrm{CaSO}_{4} \cdot 0.5 \mathrm{H}_{2} \mathrm{O}$ and $\mathrm{CaSO}_{4}$ in quantity from 20 to $80 \%$ by mass in presence of SP-2 type superplasticizer, $1 \%$ by mass, after $10 \mathrm{~min}$.

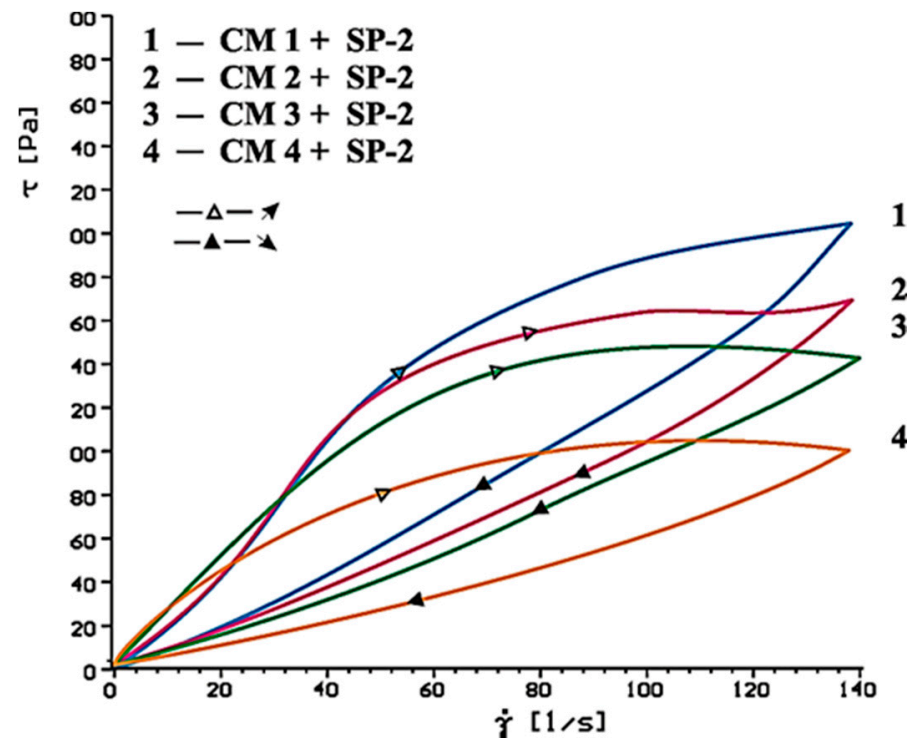

Figure 19. Flow curves of cement pastes containing $5 \%$ by mass of $\mathrm{CaSO}_{4} \cdot 0.5 \mathrm{H}_{2} \mathrm{O}$ and $\mathrm{CaSO}_{4}$ in quantity from 20 to $80 \%$ by mass in presence of SP-2 type superplasticizer, $1 \%$ by mass, after $60 \mathrm{~min}$.

Flow curves of pastes made of cements containing mixtures of sulphates (CM1-CM4) $\mathrm{z}$ with SP-1 and SP-2 superplasticizers are presented in Figures 16-19. The yield stress and plastic viscosity values determined for the pastes containing mixtures of sulphates are given in Table 6 . The yield stress and plastic viscosity values determined for the pastes containing mixtures of sulphates are given in Table 6.

The results of rheological testing of pastes made of cements containing mixtures of calcium sulphate anhydrite and hemihydrate-with different dissolution rate value (composition of cements are presented in Table 3 show that gradual increase of calcium sulphate hemihydrate content in the mixture with the anhydrite (from $20 \%$ to $80 \%$ by mass) in CM4, CM3, CM2 and CM1 cements, cause the increase of rheological parameters of pastes from these cements (Figures 14 and 15, Table 6). Therefore, the increase of $\mathrm{SO}_{4}{ }^{2-}$ sulphate ions concentration leads to gradual reduction of pastes fluidity.

In the presence of SP-1 superplasticizer, fluidity of pastes CM2, CM3, CM4 in the initial period (after $10 \mathrm{~min}$ ) remains on a similar level, except CM1 pastes, where a significant 
content of $\mathrm{CaSO}_{4} \cdot 0.5 \mathrm{H}_{2} \mathrm{O}$ may cause formation of the dihydrate, so the increase of the plastic viscosity is observed (Figure 16).

Table 6. Yield stress $\tau_{0}[\mathrm{~Pa}]$ and plastic viscosity $\eta_{\mathrm{p}}[\mathrm{Pa} \cdot \mathrm{s}]$ values of cement pastes with addition of $5 \%$ by mass of $\mathrm{CaSO}_{4} \cdot 0.5 \mathrm{H}_{2} \mathrm{O}$ and $\mathrm{CaSO}_{4}$ in quantity from 20 to $80 \%$ by mass in presence of $1 \%$ by mass of superplasticizer type: SP- 1 and SP-2.

\begin{tabular}{|c|c|c|c|}
\hline \multirow{2}{*}{ Type of Paste } & \multirow{2}{*}{ Time, $\mathrm{t}[\mathrm{min}]$} & 1\% SP1 & $1 \%$ SP2 \\
\hline & & $\begin{array}{c}\eta_{\mathrm{pl}} \\
{[\text { Pas }]}\end{array}$ & $\begin{array}{c}\eta_{\mathrm{pl}} \\
{[\text { Pas] }}\end{array}$ \\
\hline \multirow{2}{*}{$\mathrm{CM} 1\left(\right.$ Clinker $\left.+20 \% \mathrm{CaSO}_{4}+80 \% \mathrm{CaSO}_{4} \cdot 0.5 \mathrm{H}_{2} \mathrm{O}\right)$} & 10 & 0.41 & 0.36 \\
\hline & 60 & 1.33 & 1.55 \\
\hline \multirow{2}{*}{$\mathrm{CM} 2\left(\right.$ Clinker $\left.+40 \% \mathrm{CaSO}_{4}+60 \% \mathrm{CaSO}_{4} \cdot 0.5 \mathrm{H}_{2} \mathrm{O}\right)$} & 10 & 0.33 & 0.30 \\
\hline & 60 & 1.20 & 1.39 \\
\hline \multirow{2}{*}{$\mathrm{CM} 3\left(\right.$ Clinker $\left.+60 \% \mathrm{CaSO}_{4}+40 \% \mathrm{CaSO}_{4} \cdot 0.5 \mathrm{H}_{2} \mathrm{O}\right)$} & 10 & 0.32 & 0.29 \\
\hline & 60 & 0.89 & 1.05 \\
\hline \multirow{2}{*}{$\mathrm{CM} 4\left(\right.$ Clinker $\left.+80 \% \mathrm{CaSO}_{4}+20 \% \mathrm{CaSO}_{4} \cdot 0.5 \mathrm{H}_{2} \mathrm{O}\right)$} & 10 & 0.30 & 0.20 \\
\hline & 60 & 0.74 & 0.75 \\
\hline
\end{tabular}

Plastic viscosity values of $\mathrm{CM} 2, \mathrm{CM} 3, \mathrm{CM} 4$ pastes are comparable but higher than for analogous pastes containing SP-2 (Figure 20, Table 6).

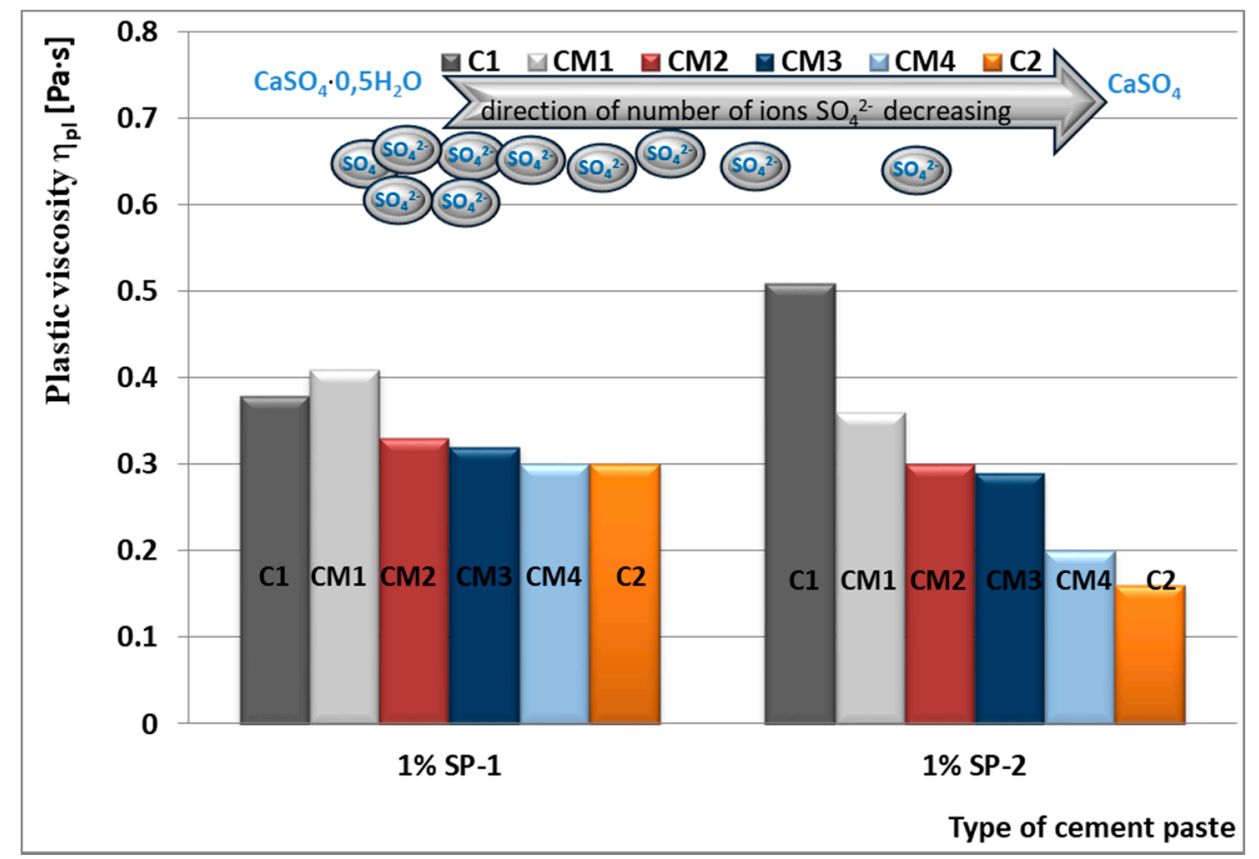

Figure 20. Plastic viscosity $\eta_{\mathrm{pl}}$ of pastes from cements $\mathrm{C} 1, \mathrm{CM} 1, \mathrm{CM} 2, \mathrm{CM} 3$ and $\mathrm{C} 2$ containing calcium sulphate anhydrite without and with $1 \%$ by mass of SP-1 and SP-2 superplasticizer, determined after $10 \mathrm{~min}$.

A different situation is observed in the paste containing SP-2 superplasticizer. The increase of $\mathrm{SO}_{4}{ }^{2}$ ion concentration by introduction of more and more calcium sulphate hemihydrate to the mixture with the anhydrite, efficiency of this superplasticizer in the initial time (10 $\mathrm{min}$.) is gradually reduced, which is demonstrated by the higher and higher plastic viscosity value of these pastes (Figures 18 and 20, Table 6).

The above test results confirm lower sensitivity of the acrylic superplasticizer to quantity of sulphates in the cement paste (in the initial period), demonstrated earlier for 
pastes of cements $\mathrm{C} 1, \mathrm{C} 2$ and $\mathrm{C} 3$. After longer time $(60 \mathrm{~min})$ the increase of paste's plastic viscosity is observed, in presence of both SP-1 and SP-2. In case SP-2 superplasticizer is used (as after $10 \mathrm{~min}$ ), the viscosity increases along with the increase of $\mathrm{SO}_{4}{ }^{2-}$ ions concentration in the paste, and thus the content of hemihydrate gypsum in the mixture with anhydrite is higher (Figures 17 and 19, Table 6).

Results of rheological testing of pastes containing various forms and different quantities of calcium sulphates $\left(\mathrm{CaSO}_{4} \cdot 0.5 \mathrm{H}_{2} \mathrm{O}\right.$ and $\left.\mathrm{CaSO}_{4}\right)$ explicitly indicate that gradual increase of sulphate ions concentration in the paste causes gradual reduction of maleic superplasticizer (SP-2) efficiency, in contrast with the acrylic superplasticizer (SP-1). In case of SP-1, the increase of sulphate ions concentration in the paste in the initial period (10 $\mathrm{min}$.) has practically no impact on its efficiency, except the paste containing a significant amount of sulphate ions, where the false bond occurrence is possible (Figure 20).

The test results indicate that SP-2 superplasticizer, which shows the highest hydrophilicity and the highest efficiency, in pastes with the proper control of the setting process (with good fluidity and addition of the setting time regulator), in case the content of $\mathrm{SO}_{4}{ }^{2-}$ ions in the paste grows, it reduces its efficiency.

The results of rheological tests of the above-mentioned pastes are analogous to results of hydration heat tests.

Curves of hydration heat evolution rates for cements $\mathrm{C} 1, \mathrm{C} 2$ and $\mathrm{C} 3$ containing various forms of the calcium sulphate, $\mathrm{CaSO}_{4} \cdot 0.5 \mathrm{H}_{2} \mathrm{O}, \mathrm{CaSO}_{4}$, and $\mathrm{CaSO}_{4} \cdot 2 \mathrm{H}_{2} \mathrm{O}$, respectively, and cements $\mathrm{CM} 1, \mathrm{CM} 2, \mathrm{CM} 3$ and $\mathrm{CM} 4$, containing mixtures of sulphates: $\mathrm{CaSO}_{4} \cdot 0.5 \mathrm{H}_{2} \mathrm{O}$ and $\mathrm{CaSO}_{4}$, with, and without $1 \%$ by mass of SP- 1 and SP- 2 superplasticizers are presented in Figures 21-26. Table 7 presents the total heat evolved for these cements after 12, 24 and $48 \mathrm{~h}$.

With the use of rheological tests, it was demonstrated that the increased concentration of sulphate ions in the paste of $\mathrm{C} 1$ cement (containing $\mathrm{CaSO}_{4} \cdot 0.5 \mathrm{H}_{2} \mathrm{O}$ ) had the influence on reduction of SP-2 maleic superplasticizer efficiency. In that case the silicate effect occurred earlier (after approx. $21 \mathrm{~h}$ of hydration) than in presence of SP-1 acrylic superplasticizer (after approx. $38 \mathrm{~h}$ ), (Table 8). It is a result of much greater delay of silicates hydration by SP-1 superplasticizer (extension of the induction period to ca. $10 \mathrm{~h}$, Figure 21).

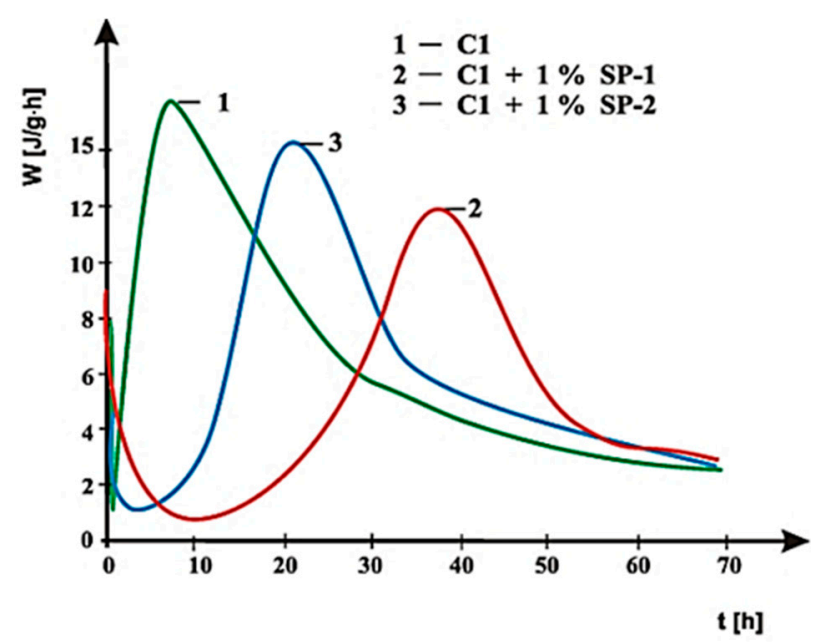

Figure 21. Hydration heat evolution rate curves for $\mathrm{C} 1$ cement without and with $1 \%$ by mass of SP-1 and SP-2 superplasticizers. 


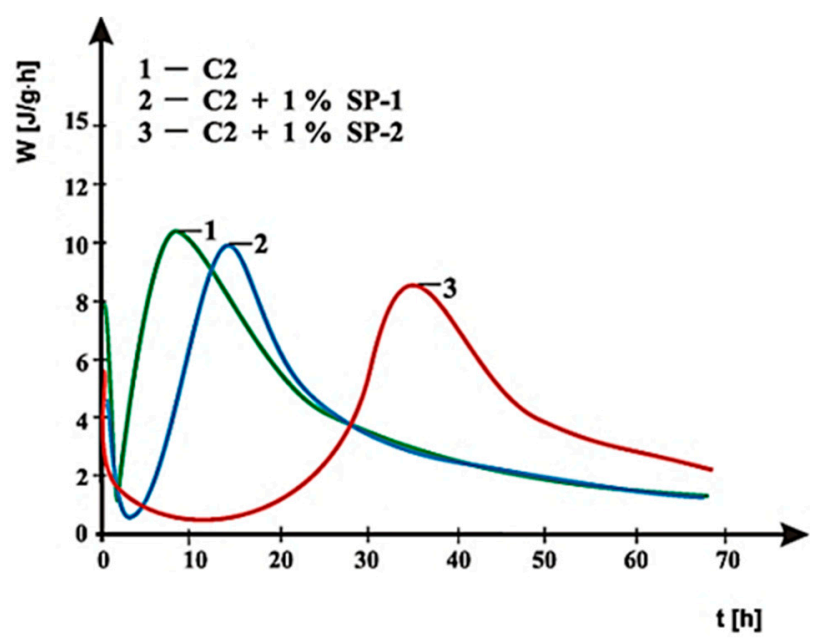

Figure 22. Hydration heat evolution rate curves for $\mathrm{C} 2$ cement without and with $1 \%$ by mass of SP-1 and SP-2 superplasticizers.

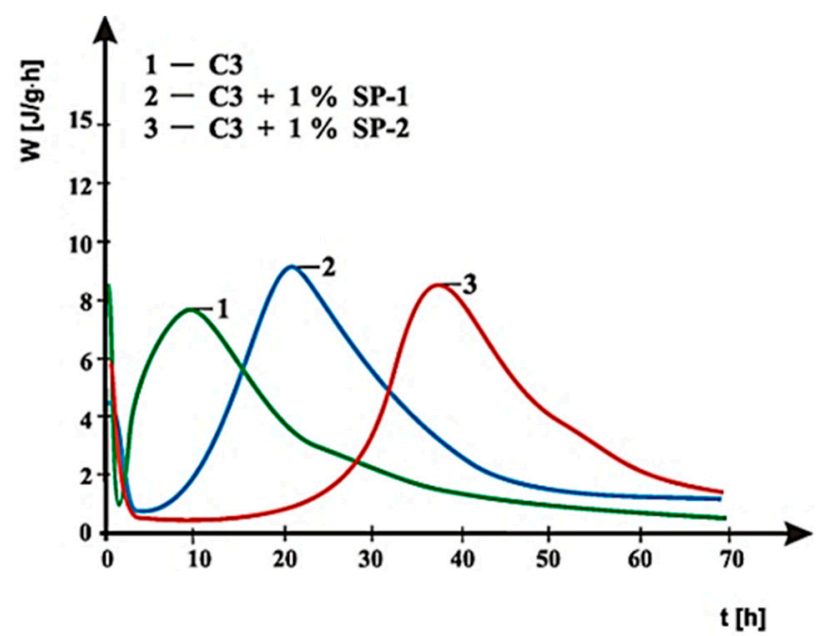

Figure 23. Hydration heat evolution rate curves for $\mathrm{C} 3$ cement without and with $1 \%$ by mass of SP-1 and SP-2 superplasticizers.

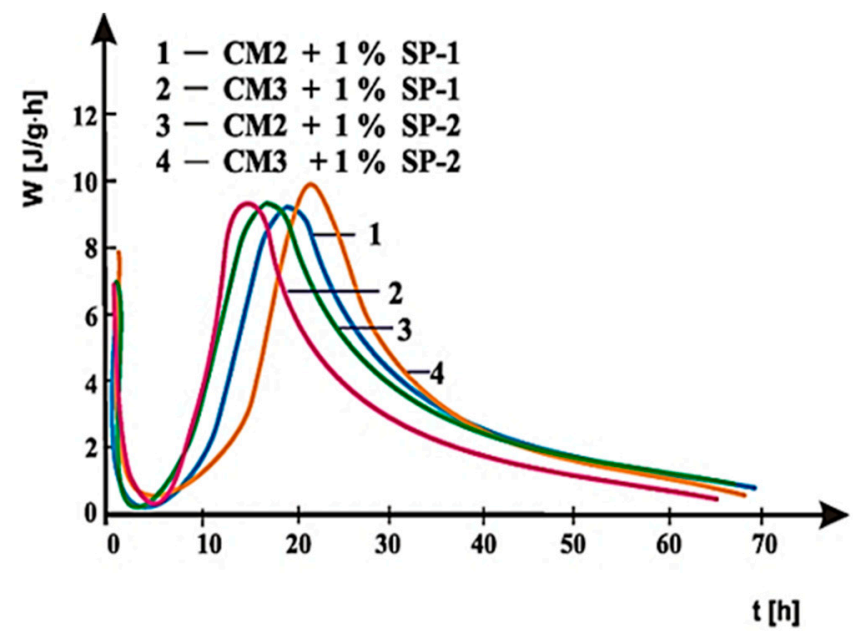

Figure 24. Hydration heat evolution rate curves for CM2 and CM3 cements with $1 \%$ by mass of SP-1 and SP-2 superplasticizers. 


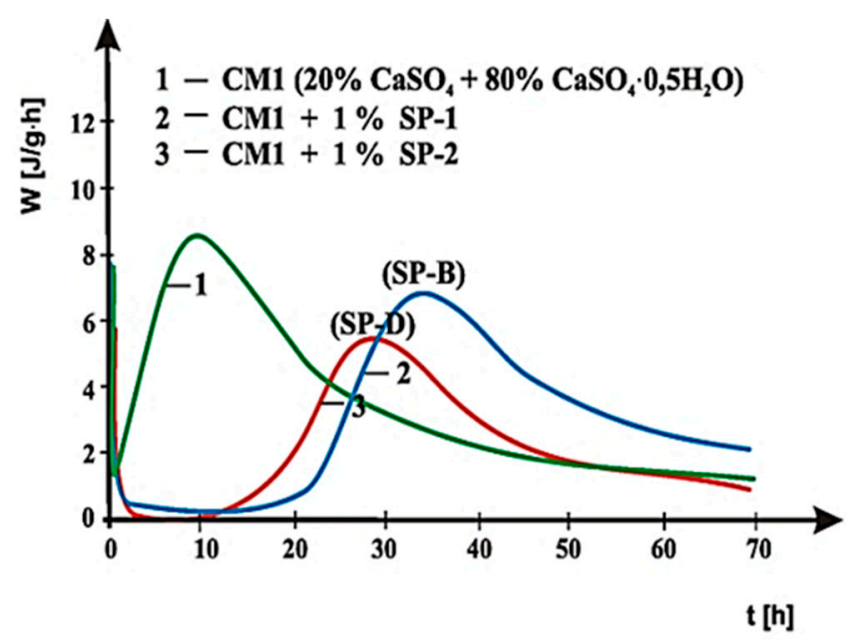

Figure 25. Hydration heat evolution rate curves for CM1 cement without and with SP-1 and SP2 superplasticizers.

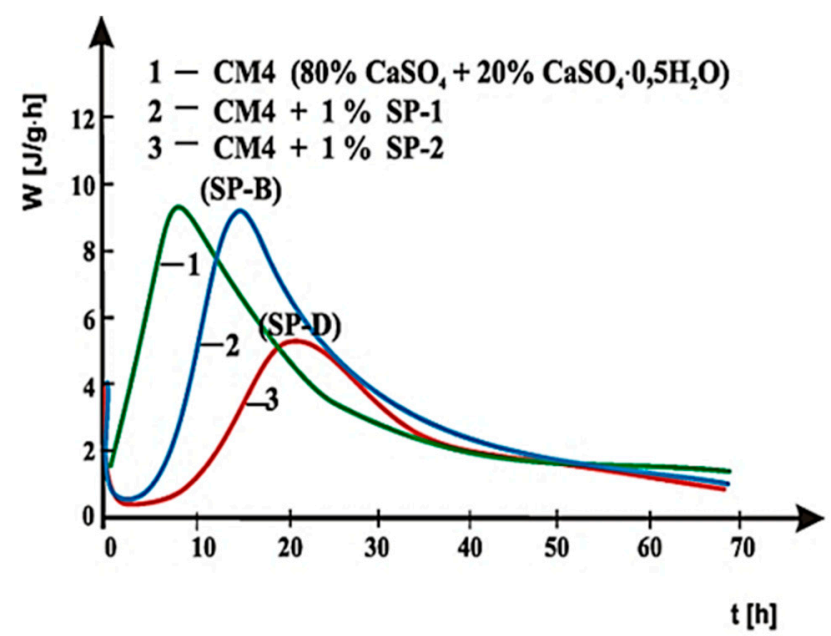

Figure 26. Hydration heat evolution rate curves for CM4 cement without and with SP-1 and SP2 superplasticizers.

As shown in Figures 21-23, the introduction of SP-1 and SP-2 superplasticizers to pastes made of C1, C2 and C3 cements causes a shift of a silicate effect on heat evolution curves towards longer time, and thus a delay of calcium silicates hydration (Table 8). Addition of the setting time regulator in a form of $\mathrm{CaSO}_{4} \cdot 0.5 \mathrm{H}_{2} \mathrm{O}$, with the highest dissolution rate, to $\mathrm{C} 1$ cement (Table 3), and thus, with the highest content of $\mathrm{SO}_{4}{ }^{2-}$ ions in the paste liquid phase, causes the increase of the silicate effect intensity, as well as the increase of the total cement hydration heat evolved, compared to pastes of C2 and C3 cements, containing sulphates with a lower dissolution rate (Figures 21-23). It results from a known impact of sulphates on acceleration of $\mathrm{C}_{3} \mathrm{~S}$ phase hydration.

A reaction between polycarboxylate groups $-\mathrm{COO}^{-}$that are present in polymer chains and $\mathrm{Ca}^{2+}$ ions from the pastes may have the impact on faster hydration of calcium silicates in the paste (at high concentration of sulphate ions) containing SP-2 superplasticizer compared to SP-1 superplasticizer. On one hand it leads to reduced quantity of the active polymer in the solution in result of its building into chelates being formed $[53,54]$. On the other hand, binding of carboxylate groups into chelate complexes with calcium ions may lead to faster transition of $\mathrm{Ca}^{2+}$ ions to solution from $\mathrm{C}_{3} \mathrm{~S}$ phase $[38,55]$, which could explain accelerated hydrolysis of silicate phases in presence of SP-2 superplasticizer. 
Table 7. Total hydration heat evolved for C1, C2, C3, as well as CM1, CM2, CM3 and CM4 cements without and with SP-1 and SP-2 superplasticizers.

\begin{tabular}{|c|c|c|c|}
\hline \multirow[t]{2}{*}{ Type of Paste } & \multicolumn{3}{|c|}{$\begin{array}{c}\text { Quantity of Heat Evolved [J/g] } \\
\text { after }\end{array}$} \\
\hline & $12 \mathrm{~h}$ & $24 \mathrm{~h}$ & $48 \mathrm{~h}$ \\
\hline $\mathrm{C} 1$ & 131.7 & 264.1 & 383.0 \\
\hline $\mathrm{C} 1+\mathrm{SP}-1$ & 42.7 & 148.1 & 317.2 \\
\hline $\mathrm{C} 1+\mathrm{SP}-2$ & 17.3 & 134.9 & 201.4 \\
\hline $\mathrm{C} 2$ & 93.7 & 171.5 & 251.1 \\
\hline $\mathrm{C} 2+\mathrm{SP}-1$ & 30.7 & 111.4 & 242.5 \\
\hline $\mathrm{C} 2+\mathrm{SP}-2$ & 5.2 & 16.8 & 159.2 \\
\hline C3 & 66.5 & 122.6 & 160.4 \\
\hline $\mathrm{C} 3+\mathrm{SP}-1$ & 3.1 & 71.5 & 138.7 \\
\hline $\mathrm{C} 3+\mathrm{SP}-2$ & 2.6 & 19.3 & 81.6 \\
\hline CM1 & 66.1 & 133.2 & 191.5 \\
\hline CM1 + SP-1 & 1.7 & 5.0 & 126.1 \\
\hline $\mathrm{CM} 1+\mathrm{SP}-2$ & 4.2 & 28.6 & 125.8 \\
\hline CM2 & 68.7 & 137.2 & 193.4 \\
\hline $\mathrm{CM} 2+\mathrm{SP}-1$ & 10.5 & 101.4 & 184.4 \\
\hline $\mathrm{CM} 2+\mathrm{SP}-2$ & 5.9 & 52.9 & 160.3 \\
\hline CM3 & 69.5 & 138.9 & 198.6 \\
\hline $\mathrm{CM} 3+\mathrm{SP}-1$ & 30.2 & 117.9 & 185.4 \\
\hline $\mathrm{CM} 3+\mathrm{SP}-2$ & 5.5 & 84.5 & 180.8 \\
\hline CM4 & 71.6 & 140.6 & 205.1 \\
\hline $\mathrm{CM} 4+\mathrm{SP}-1$ & 23.2 & 112.7 & 191.3 \\
\hline $\mathrm{CM} 4+\mathrm{SP}-2$ & 7.2 & 57.1 & 122.6 \\
\hline
\end{tabular}

Table 8. Location of the silicate effect for pastes containing SP-1 and SP-2 superplasticizers in time [hours].

\begin{tabular}{ccc}
\hline Type of Cement & SP-1 & SP-2 \\
\hline C1 & 38 & 21 \\
\hline C2 & 13 & 35 \\
\hline C3 & 21 & 38 \\
\hline CM1 & 34 & 28 \\
\hline CM2 & 16 & 18 \\
\hline CM3 & 14 & 21 \\
\hline CM4 & 13.5 & 22 \\
\hline
\end{tabular}

Replacement of the calcium sulphate hemihydrate with sulphates that have lower dissolution rate $\left(\mathrm{CaSO}_{4}\right.$ and $\left.\mathrm{CaSO}_{4} \cdot 2 \mathrm{H}_{2} \mathrm{O}\right)$ causes a reduction of intensity and the delay in time of the silicate effect location on the heat evolution rate curve, depending on the type of the superplasticizer. For $\mathrm{C} 2$ cement that contains anhydrite $\left(\mathrm{CaSO}_{4}\right)$ in the presence of SP-1 superplasticizer the silicate effect was observed after ca. $13 \mathrm{~h}$, while for $\mathrm{C} 3$ cement with a dihydrate gypsum - after $21 \mathrm{~h}$ (Figures 22 and 23). 
In the presence of SP-2 superplasticizer, the silicate effect was observed after a lapse of ca. $35 \mathrm{~h}$, whereas for $\mathrm{C} 3$ cement after ca. $38 \mathrm{~h}$, with the induction period extended to ca. $15 \mathrm{~h}$ (Figures 22 and 23).

The above test results indicate that SP-2 superplasticizer in $\mathrm{C} 2$ and $\mathrm{C} 3$ cements delays hydration of silicates to a larger extent than SP-1 superplasticizer. It is also confirmed by the results of hydration heat testing for cements CM1, CM2, CM3 and CM4 (Figures 24-26, Table 7), containing calcium sulphates $\left(\mathrm{CaSO}_{4} \cdot 0.5 \mathrm{H}_{2} \mathrm{O}\right.$ and $\left.\mathrm{CaSO}_{4}\right)$ as the setting time regulator. It is illustrated by Figures 25 and 26, where for comparison, curves of cements hydration heat evolution rates are presented in the presence of SP- 1 and SP2 superplasticizer, with the highest and the lowest content of sulphate ions, respectively. A reduction in sulphate ions concentration in $\mathrm{CM} 4$ cement by application of a mixture composed of sulphates containing $80 \%$ by mass of $\mathrm{CaSO}_{4}$ and $20 \%$ of $\mathrm{CaSO}_{4} \cdot 0.5 \mathrm{H}_{2} \mathrm{O}$, in the presence of SP-1 superplasticizer, leads to appearance of the silicate effect already after ca. $13.5 \mathrm{~h}$. Whereas, in the presence of SP-2 superplasticizer, this effect appears only after ca. $22 \mathrm{~h}$ of hydration, and its intensity is much reduced (Figure 26). The highest concentration of sulphate ions ( $20 \%$ by mass of $\mathrm{CaSO}_{4}$ and $80 \%$ of $\mathrm{CaSO}_{4} \cdot 0.5 \mathrm{H}_{2} \mathrm{O}$ ) leads to appearance of the silicate effect in presence of SP-2 maleic superplasticizer after ca. $28 \mathrm{~h}$, compared to location of that effect in presence of SP-1 acrylic superplasticizer observed only after ca. $34 \mathrm{~h}$, i.e., $6 \mathrm{~h}$ later. The induction period in this case is extended to ca. $15 \mathrm{~h}$ (Figure 25). A similar relationship was also found for $\mathrm{CM} 2$ and $\mathrm{CM} 3$ cements, and the induction period in those cements was extended to $5 \mathrm{~h}$ (Figure 24) and for CM2 SP2 seems to shift the peak heat time (Location of the silicate effect) to the left compared to SP1 the opposite is evident for CM3. The observed difference in the rate of appearance of the silicate effect, originating from the hydration of silicate phases for cements, CM2 and CM3, in the presence of SP-1 and SP-2 superplasticizers, results from differences in composition of these cements and specifically in the type and amount of sulphates used, as well as sensitivity of the superplasticizer to the presence of $\mathrm{SO}_{4}{ }^{2-}$ ions. This is related to the different availability of $\mathrm{SO}_{4}{ }^{2-}$ ions in the cement paste depending on the sulphate dissolution rate (Table 3).

Therefore, the lower concentration of sulphate ions in the paste of CM3 cement compared to CM2 cement is due to the sulphate mixture used in their composition containing respectively: $\left(40 \%\right.$ by mass $\mathrm{CaSO}_{4}$ and $\left.60 \% \mathrm{CaSO}_{4} \cdot 0.5 \mathrm{H}_{2} \mathrm{O}\right)$ in $\mathrm{CM} 2$ and $(60 \%$ by mass $\mathrm{CaSO}_{4}$ and $40 \% \mathrm{CaSO}_{4} \cdot 0.5 \mathrm{H}_{2} \mathrm{O}$ ) in $\mathrm{CM} 3$ (Figure 24). As can be seen, $\mathrm{CM} 2$ cement contains more sulphate hemihydrate $\left(60 \% \mathrm{CaSO}_{4} \cdot 0.5 \mathrm{H}_{2} \mathrm{O}\right)$ with a higher dissolution rate, which directly affects the higher availability of sulphate ions in the paste. As shown by rheological and heat of hydration testing, maleic superplasticizer SP-2 shows less effective performance in the presence of increased concentration of sulphate ions $\left(60 \% \mathrm{CaSO}_{4} \cdot 0.5 \mathrm{H}_{2} \mathrm{O}\right.$ in CM2), other than in the presence of SP-1 acrylic superplasticizer. This is confirmed by the accelerated hydration and setting process of CM2 cement in the presence of SP-2, which is associated with a faster loss of this paste fluidity and an accelerated in time appearance of the silicate effect on the heat evolution rate curve than for $\mathrm{CM} 2$ cement paste. On the other hand, the content of $\mathrm{CaSO}_{4} \cdot 0.5 \mathrm{H}_{2} \mathrm{O}$ reduced to $40 \%$ by mass in $\mathrm{CM} 3$ cement introduces a smaller amount of $\mathrm{SO}_{4}{ }^{2-}$ ions, which in the paste containing SP-2 maleic superplasticizer, leads to its higher fluidity and time-delayed appearance of the maximum silicate effect. In this case, the acrylic superplasticizer is less effective.

The above can be explained by the fact that the silicate effect appears earlier in sulphate ion-rich pastes (containing $\left.\mathrm{CaSO}_{4} \cdot 0.5 \mathrm{H}_{2} \mathrm{O}\right)(\mathrm{CM} 2)$, which is related to the accelerated hydration of calcium silicates.

The greater delay of silicate hydration in the presence of SP-1 acrylic superplasticizer confirmed its greater performance at increased sulphate ion concentration. Under these conditions, the less efficient maleic superplasticizer delays hydration of calcium silicates to the lesser extent than the acrylic superplasticizer.

The heat of hydration tests of cements in the presence of superplasticizers confirmed a relationship between the delay of the cement hydration process and the superplasticizer performance. Maleic superplasticizer (SP-2), with higher hydrophilicity and performance 
in pastes with proper regulation of the setting process (with lower concentration of sulphate ions) like in CM3, delays hydration of silicates to a greater extent than acrylic superplasticizer (SP-1), in the presence of an earlier the silicate effect, which appears earlier on the heat evolution rate curve (which indicates accelerated hydration).

The higher performance of SP-2 maleic superplasticizer compared to acrylic SP-1 is related to the presence of higher amount of hydrophilic, carboxyl and polyoxyethylene groups in the flexible comb-like structure in the maleic superplasticizer. The backbone chain, adsorbing on the cement grains through a large number of carboxylate groups $\left(\mathrm{COO}^{-}\right)$, effectively prevents flocculation of cement grains due to the presence of very long hydrophilic polyoxyethylene chains, which leads to increased fluidity of the paste and a time-delayed hydration process of the silicate phases.

However, in the case of acrylic superplasticizer, the very small number of carboxylate groups and the shorter side chains in the strengthened ladder-like structure of this superplasticizer cause a smaller range of action in the cement paste (loss of fluidity and accelerated hydration).

In contrast, the performance of the maleic superplasticizer decreases with increasing sulphate ion concentration in the cement paste. Under these conditions the maleic superplasticizer inhibits formation of the gypsum dihydrate. The lower performance of the maleic superplasticizer at high sulphate ion content is most likely due to the competition of the large amount of $\mathrm{SO}_{4}^{2-}$ ions in the paste with the $\mathrm{COO}^{-}$carboxylate groups of the superplasticizer for the active centres occupied by positive ions $\mathrm{Ca}^{2+}$ on the cement grain surface, preventing their adsorption. Therefore, based on increased sulphate ion concentration, binding of carboxylate groups into chelate complexes with calcium ions is likely. This may lead to a faster $\mathrm{Ca}^{2+}$ ions transition to solution from the $\mathrm{C}_{3} \mathrm{~S}$ phase, which would explain the accelerated hydrolysis of the silicate phase in the presence of SP-2 maleic superplasticizer.

While, in the case of the acrylic superplasticizer, due to a very small quantity of $\mathrm{COO}^{-}$ groups, adsorption may occur with partial negative charges formed in result of polarity of bonds in ester groups of the backbone chain. Shorter polyoxyethylene side chains that connect the backbone chain, increase a distance between cement grains, leading to their deffloculation. In that case, the higher availability of sulphate ions in the paste, to a lesser extent, hinders the formation of the steric block and may explain the higher performance of the acrylic superplasticizer in pastes containing gypsum hemihydrate with the high dissolution rate.

It should be emphasized that tests conducted in this study show that sulphates definitely change performance of polycarboxylate superplasticizers. The high concentration of sulphate ions reduces the performance of the maleic superplasticizer. Under these conditions, the acrylic superplasticizer is more effective and is more suitable for fluidity of pastes with higher $\mathrm{SO}_{4}{ }^{2-}$ ion content. Therefore, sulphate ions concentration in the paste should be taken into account when the superplasticizer choice is made.

It is emphasized that superplasticizer hydrophilicity, adopted in this paper to assess its performance in cement pastes, allows for better prediction of its behavior in the cement paste (with various composition of a liquid phase), as it takes into account the mechanisms of interaction between individual elements of the superplasticizer structure with the cement paste phases.

As in case of $\mathrm{C} 1, \mathrm{C} 2$ and $\mathrm{C} 3$ cements containing the following as the setting time regulator: $\mathrm{CaSO}_{4} \cdot 0.5 \mathrm{H}_{2} \mathrm{O}, \mathrm{CaSO}_{4}$, and $\mathrm{CaSO}_{4} \cdot 2 \mathrm{H}_{2} \mathrm{O}$, respectively, and in the case of $\mathrm{CM} 1, \mathrm{CM}$, $\mathrm{CM} 3$ and $\mathrm{CM} 4$ containing mixtures of calcium sulphates (hemihydrate and anhydrite), reduced total heat evolved is observed along with the increase of the admixture efficiency in the cement paste (Table 7).

Hydration heat tests of cements, in the presence of superplasticizers, showed a relation between the delay of the hydration process of calcium silicates in the cement and efficiency of the superplasticizer in the cement paste. The maleic superplasticizer (SP-2), with higher efficiency, in pastes containing $\mathrm{CaSO}_{4}$ and $\mathrm{CaSO}_{4} \cdot 2 \mathrm{H}_{2} \mathrm{O}$, with lower concentration of 
sulphate ions, delays hydration of silicates to a greater extent than SP-1 superplasticizer with the lower efficiency. Whereas, in pastes with high concentration of sulphate ions, a reverse effect is observed. In these conditions, less efficient SP-2 superplasticizer delays hydration of calcium silicates to the lesser extent than SP-1 acrylic superplasticizer.

Furthermore, comparing the values of Table 8 it is clear that SP-2 is delaying the silicate effect compared to SP-1 in all cases except C1 and CM1. It is closely related to the discussion presented above on the performance of SP- 1 and SP-2 superplasticizers and the type of calcium sulphate used $\left(\mathrm{CaSO}_{4}, \mathrm{CaSO}_{4} \cdot 2 \mathrm{H}_{2} \mathrm{O}, \mathrm{CaSO}_{4} \cdot 0.5 \mathrm{H}_{2} \mathrm{O}\right)$ with different dissolution rates in $\mathrm{C}$ and $\mathrm{CM}$ cements, observed in the course of silicate phases hydration during heat of hydration tests of these cements.

Cements $\mathrm{C} 1$ and $\mathrm{CM} 1$ show the higher content of $\mathrm{CaSO}_{4} \cdot 0.5 \mathrm{H}_{2} \mathrm{O}$-sulphate hemihydrate-with the highest dissolution rate, which translates into increased availability of sulphate ions. The $\mathrm{C} 1$ cement contains, respectively: $100 \%$ by mass $\mathrm{CaSO}_{4} \cdot 0.5 \mathrm{H}_{2} \mathrm{O}$ and CM1 its content amounts to $80 \%$ by mass. Therefore, for these cements, in the environment of increased concentration of sulphate ions in the paste, the increase in the total heat evolution and acceleration of the hydration process is observed with simultaneous lower performance of SP-2 maleic superplasticizer demonstrated.

\section{Discussion}

The paper contains the analysis of efficiency of polycarboxylate superplasticizers, ester derivatives of the acrylic acid and maleic anhydride after their esterification with polyoxyethylene glycols (PEG) with various molar mass, in cement pastes.

The chemical structure of superplasticizers used was determined with the use of the gel permeation chromatography (GPC) and infrared absorption spectroscopy (FTIR). It was found that superplasticizers-derivatives of the maleic acid-showed a high molecular weight and were built of polymaleic backbone chains and very long polyoxyethylene side chains.

It was demonstrated that acrylic superplasticizers had lower molar mass, and they were built of polyacrylic backbone chains and a larger amount of shorter polyoxyethylene side chains.

As a measure of superplasticizers efficiency, their hydrophilicity was adopted, determined by means of a hydrophilicity coefficient expressed as a ratio of ether band absorbance $\mathrm{A}_{\mathrm{ET}}{ }^{1110}$ (STR $\mathrm{CH}_{2}-\mathrm{O}-\mathrm{CH}_{2 \mathrm{ET}}$ ) of hydrophilic oxyethylene groups to ester band absorbance $\mathrm{A}_{\mathrm{ES}}{ }^{1730-40}$ (STR $\mathrm{C}=\mathrm{O}_{\mathrm{ES}}$ ) of hydrophobic ester groups $\mathrm{O}=\mathrm{C}-\mathrm{O}-\mathrm{C}$ (with constant content of aliphatic groups).

Higher hydrophilicity of maleic superplasticizers compared to acrylic superplasticizers results from a larger content of hydrophilic groups than hydrophobic groups in these superplasticizers, as well as additional increase of hydrophilicity of this superplasticizer in result of carboxylate groups $\left(\mathrm{COO}^{-}\right)$formation from hydrolysis of anhydrides and maleic acids in the cement paste environment.

Based on rheological testing of cement pastes it was found that along with the increase of hydrophilicity of acrylic and maleic superplasticizers, their efficiency increased in pastes containing calcium sulphates $\mathrm{CaSO}_{4} \cdot 2 \mathrm{H}_{2} \mathrm{O}$ and $\mathrm{CaSO}_{4}$, which ensured the effective delay of $\mathrm{C}_{3} \mathrm{~A}$ hydration. The higher efficiency of the maleic superplasticizer compared to acrylic one is associated with presence of hydrophobic, carboxylate and polyoxyethylene groups in the maleic superplasticizer. The backbone chain of that superplasticizer by being adsorbed on cement grains by a large quantity of carboxylate groups $\left(\mathrm{COO}^{-}\right)$effectively prevents flocculation of cement grains, due to the very long hydrophilic polyoxyethylene side chains, which leads to higher fluidity of the paste.

In case of the acrylic superplasticizer, a very small amount of carboxylate groups, as well as shorter side chains in the rigid, ladder-shaped structure of that superplasticizer, cause a smaller range of its activity in the cement paste.

It was found that the efficiency of the maleic superplasticizer got lower along with the increase of sulphate ions concentration in the cement paste. In those conditions the maleic superplasticizer inhibited formation of the gypsum dihydrate. Lower efficiency 
of the maleic superplasticizer with high content of sulphate ions in the cement paste most likely results from competition of $\mathrm{SO}_{4}{ }^{2-}$ ions with carboxylate groups-COO${ }^{-}$of the superplasticizer for active centers occupied by $\mathrm{Ca}^{2+}$ ions on the surface of cement grains, which reduces their possible adsorption.

In case of the acrylic superplasticizer, due to a very small quantity of $\mathrm{COO}^{-}$groups, adsorption may occur with partial negative charges formed in result of polarity of bonds in ester groups of the backbone chain. Shorter polyoxyethylene side chains that connect the backbone chain, increase a distance between cement grains, leading to their deflocculation. In that case the high concentration of sulphate ions in the paste, to a lesser extent, hinders the formation of the spherical blockade, and may explain the higher efficiency of the acrylic superplasticizer in pastes containing gypsum hemihydrate with the high dissolution rate.

According to the research conducted by the author, sulphates definitely change efficiency of polycarboxylate superplasticizers. High concentration of sulphate ions lowers maleic superplasticizer efficiency. In such conditions, the acrylic superplasticizer is more effective, therefore, it is better to fluctuate suspensions containing more $\mathrm{SO}_{4}{ }^{2-}$ ions. Therefore, sulphate ion concentration in the paste should be taken into account when the superplasticizer choice is made.

Hydration heat tests of cements in presence of superplasticizers confirmed a relation between the delay of the cement hydration process and the superplasticizer efficiency. The higher efficiency of the superplasticizer, the higher delay of hydration is. The maleic superplasticizer with higher hydrophilicity and efficiency in pastes with proper setting process regulation by addition of the calcium sulphate $\left(\mathrm{CaSO}_{4} \cdot 2 \mathrm{H}_{2} \mathrm{O}, \mathrm{CaSO}_{4}\right)$ delays hydration of silicates to a greater extent than less efficient acrylic superplasticizer (the silicate effect appears on the heat evolution rate curve with a great delay.

In pastes with a larger content of sulphate ions (containing $\mathrm{CaSO}_{4} \cdot 0.5 \mathrm{H}_{2} \mathrm{O}$ ), the silicate effect appears earlier, which is associated with acceleration of silicates hydration. The greater delay of silicates hydration in the presence of the acrylic superplasticizer showed better efficiency of that superplasticizer found at the higher concentration of sulphate ions. In these condition the less efficient maleic superplasticizer (containing a larger amount of $\mathrm{COO}^{-}$groups) delays hydration of calcium silicates to a lesser extent than the acrylic superplasticizer (SP-1). It is most likely caused by a reaction occurring between non-adsorbed $\mathrm{COO}^{-}$carboxylate groups present in the superplasticizer backbone chain and calcium ions $\mathrm{Ca}^{2+}$ present in the cement paste. Binding of carboxylate groups into chelate complexes with calcium ions may lead to faster transition of $\mathrm{Ca}^{2+}$ ions to solution from $\mathrm{C}_{3} \mathrm{~S}$ phase, which could explain accelerated hydrolysis of the silicate phase in presence of the maleic superplasticizer (SP-2).

Based on superplasticizer hydrophilicity determined, as well as rheological testing and hydration heat tests, a relation between the content of hydrophilic groups and efficiency of the superplasticizer was defined:

$$
\mathrm{S}=\mathrm{x} \cdot\left(\mathrm{OCH}_{2} \mathrm{CH}_{2}\right)_{\mathrm{n}} \text {, for } \mathrm{O}=\mathrm{C}-\mathrm{O}-\mathrm{C}=\text { const }
$$

where: $S$-superplasticizer efficiency

$\mathrm{x}$-a number of polyoxyethylene (polyether) chains

$\mathrm{n}$-a length of oxyethylene mers

On that basis, it was found that, along with the increase of a number and the length of polyether side chains, at the constant content of ester groups in the superplasticizer, the superplasticizer efficiency increased: SP-1 $<$ SP-2.

In addition it was found that efficiency of the superplasticizer was proportional to its hydrophilicity expressed by the hydrophilicity coefficient, and inversely proportional to viscosity of the paste:

$$
S=\frac{A^{1110} / A^{1730}}{\eta_{p l}}
$$

where: $A^{1110} / A^{1730}$-hydrophilicity coefficient 
$\eta_{p l}$-viscosity

It shall be emphasized that superplasticizer hydrophilicity adopted in this paper to assess the efficiency in cement pastes is a parameter that allows better prediction of its efficiency in cement pastes due to the content of $C_{3} A$ phase and sulphate ions in the cement paste.

Therefore, the knowledge of superplasticizer hydrophilicity may be an essential help while selecting a type of superplasticizer admixture in technology of cement-based composite building materials.

Moreover the maleic acid is a stronger acid $\left(\mathrm{K}_{1}=1.2 \times 10^{-2}\right)$ than the acrylic acid $\left(\mathrm{K}=5053 \times 10^{-5}\right)$, therefore it forms $\mathrm{COO}^{-}$ions easier than the acrylic acid:

$$
\mathrm{CaSO}_{4} \rightleftarrows \mathrm{Ca}^{2+}+\mathrm{SO}_{4}{ }^{2-}
$$

Sulphate ions originating from $\mathrm{CaSO}_{4}$ dissociation may compete with $\mathrm{COO}^{-}$carboxylate ions present in the superplasticizer backbone chain in the process of electrostatic anchoring on the local positive charges on the surface of cement grains. Therefore, along with the increase of $\mathrm{SO}_{4}{ }^{2-}$ concentration, the desorption of carboxylate groups from the surface of cement grains may occur or the adsorption of these groups may be hindered. Along with the increase of $\mathrm{SO}_{4}{ }^{2-}$ concentration, the ionic strength grows, which causes shrinking (curling) of carboxylate and ether chains, and reduction of adsorption of carboxylate groups on the cement grains surface, as well as desorption of SP chains already anchored on the cement surface may occur. Also $\mathrm{Ca}^{2+}$ ions, coming from $\mathrm{CaSO}_{4}$ dissociation, neutralize $\mathrm{COO}^{-}$carboxylate groups of the superplasticizer causing their deactivation through formation of calcium acrylates or calcium maleates (with a lower dissolution rate and slower dissociation in water than calcium acrylates or sodium maleates). The lower activity of the maleic superplasticizer than the acrylic superplasticizer in presence of high concentration of $\mathrm{Ca}^{2+}$ and $\mathrm{SO}_{4}{ }^{2-}$, may be caused by lower dissolution rate in water of calcium maleates compared to calcium acrylates.

Knowledge of superplasticizer hydrophilicity may provide essential help during the selection of a superplasticizer admixture in cement-based concrete technology.

\section{Conclusions}

Based on analyses of chemical composition and structure of superplasticizers, as well as their efficiency in cement pastes containing different amount of the $\mathrm{SO}_{4}{ }^{2-}$ ions that depends on the dissolution rate of sulphates used, it was found that:

- A superplasticizer efficiency depends on its molecular structure. The most significant features are: Hydrophilicity, pure polymer content, weight-averaged molecular mass $(\mathrm{Mw})$ of the superplasticizer polymer, presence of free carboxylic acids and anhydrides in solid samples, content of free poly(ethylene glycols) non-reacted with acid and anhydride.

- $\quad$ SP-2 superplasticizer that contains the shorter backbone chain, long side chains and greater number of carboxylate groups $\left(\mathrm{COO}^{-}\right)$shows higher hydrophilicity than SP-1 superplasticizer that is built of the longer backbone chain with shorter side chains and contains fewer $\mathrm{COO}^{-}$groups.

- It was found that the superplasticizer (SP-2), with the higher hydrophilicity showed the higher efficiency in pastes containing calcium sulphates (gypsum dihydrate and anhydrite) used as the setting time regulator, than the superplasticizer with lower hydrophilicity (SP-1), despite belonging to the same polycarboxylate group.

- SP-1 superplasticizer with lower hydrophilicity and shorter side chains with the long backbone chain that contains small number of $\mathrm{COO}^{-}$group, is more resistant to the impact of sulphates. The increase of $\mathrm{SO}_{4}{ }^{2-}$ ions content in the paste by the introduction of $\mathrm{CaSO}_{4} \cdot 0.5 \mathrm{H}_{2} \mathrm{O}$ or increasing amounts of $\mathrm{CaSO}_{4} \cdot 0.5 \mathrm{H}_{2} \mathrm{O}$ in the mixture with $\mathrm{CaSO}_{4}$ generally does not change the viscosity of pastes, but it does promote greater delay of silicates hydration. 
- In case of SP-2 superplasticizer that shows higher hydrophilicity and has the short backbone chain and more $\mathrm{COO}^{-}$groups (which suggests its better efficiency) the increase of $\mathrm{SO}_{4}{ }^{2-}$ ions content in the paste by introduction of $\mathrm{CaSO}_{4} \cdot 0.5 \mathrm{H}_{2} \mathrm{O}$ or increasing amount of $\mathrm{CaSO}_{4} \cdot 0.5 \mathrm{H}_{2} \mathrm{O}$ in the mixture with $\mathrm{CaSO}_{4}$, causes deterioration of rheological properties (reduction of fluidity degree) and affects the acceleration of silicates hydration.

Funding: This research received no external funding.

Institutional Review Board Statement: Not applicable.

Informed Consent Statement: Not applicable.

Data Availability Statement: Data is contained within the article.

Conflicts of Interest: The author declares no conflict of interest.

\section{References}

1. Ma, B.; Peng, Y.; Tan, H.; Lv, Z.; Deng, X. Effect of Polyacrylic Acid on Rheology of Cement Paste Plasticized by Polycarboxylate. Materials 2018, 11, 1081. [CrossRef]

2. Pelletier-Chaignat, L.; Winnefeld, F.; Lothenbach, B.; Saout, G.L.; Müller, C.J; Famy, C. Influence of the Calcium Sulphate Source on the Hydration Mechanism of Portland Cement-Calcium Sulphoaluminate Clinker-Calcium Sulphate Binders. Cem. Concr. Compos. 2011, 33, 551-561. [CrossRef]

3. Locher, R.W.; Richartz, W.; Sprung, S. Erstarren von Zement. Teil II: Einfluß des Calciumsulfatzusatzes. Zem. Kalk Gips 1980, 33, 271-277. (In German)

4. Borsoi, A.; Collepardi, S.; Copolla, L.; Troli, R.; Collepardi, E.M. Advances in Superplasticizers for Concrete Mixtures. Il Cemento 1999, 69, 234-244.

5. Hu, K.; Sun, Z; Yang, H. Effects of Polycarboxylate Superplasticizers with Different Functional Units on the Early Hydration Behavior of Cement Paste. J. Mater. Civ. Eng. 2019. [CrossRef]

6. Kong, F.R.; Pan, L.S.; Wang, C.M.; Xu, N. Effects of Polycarboxylate Superplasticizers with Different Molecular Structure on the Hydration Behavior of Cement Paste. Constr. Build. Mater. 2016, 105, 545-553. [CrossRef]

7. Ohta, A.; Sugiyama, T.; Tanaka, Y. Fluidizing Mechanism and Application of Polycarboxylate-Based Superplasticizers. In Proceedings of the 5th CANMET/ACI International Conference on Superplasticizers and Other Chemical Admixtures in Concrete (ACI. SP173), Rome, Italy, 7-10 October 1997; Malhotra, V.M., Ed.; American Concrete Institute: Farmington Hills, MI, USA, 1997; pp. 359-378.

8. Wu, H.; Guo, H.; Lei, J.; Zhang, R.; Liu, Y. Research on Synthesis and Action Mechanism of Polycarboxylate Superplasticizer. Front. Chem. China 2007, 2, 322-325. [CrossRef]

9. Uchikawa, H.; Hanechara, S.; Sawaki, D. The Role of Steric Repulsive Force in the Dispersion of Cement Particles with Organic Admixtures. Cem. Concr. Res. 1997, 27, 37-50. [CrossRef]

10. Ran, Q.P.; Somasundara, P.; Miao, C.W.; Liu, J.P.; Shen, W.P. Effect of the Length of the Side Chains of Comb-Like Copolymer Dispersants on Dispersion and Rheological Properties of Concentrated Cement Suspensions. J. Colloid Interface Sci. 2009, 336, 624-633. [CrossRef]

11. Liu, X.; Guan, J.; Lai, G.; Wang, Z.; Zhu, J.; Cui, S.; Lan, M.; Li, H. Performances and Working Mechanism of a Novel Polycarboxylate Superplasticizer Synthesized through Changing Molecular Topological Structure. J. Colloid Interface Sci. 2017, 504, 12-24. [CrossRef]

12. Holly, R.; Peemoeller, H.; Zhang, M.; Reardon, E.; Hansson, C.M. Magnetic Resonance in Situ Study of Tricalcium Aluminate Hydration in the Presence of Gypsum. J. Am. Ceram. Soc. 2006, 89, 1022-1027. [CrossRef]

13. Plank, J.; Hirsch, C. Impact of Zeta Potential of Early Cement Hydration Phases on Superplasticizer Adsorption. Cem. Concr. Res. 2007, 37, 537-542. [CrossRef]

14. Plank, J.; Pöllmann, K.; Zouaoui, N.; Andres, P.R.; Schaefer, C. Synthesis and Performance of Methacrylic Ester Based Polycarboxylate Superplasticizers Possessing Hydroxy Terminated Poly(Ethylene Glycol) Side Chains. Cem. Concr. Res. 2008, 38, 1210-1216. [CrossRef]

15. Yoshioka, K.; Tazawa, E.I.; Kawai, K.; Enohata, T. Adsorption Characteristics of Superplasticizers on Cement Component Minerals. Cem. Concr. Res. 2002, 32, 1507-1513. [CrossRef]

16. Plank, J.; Sachsenhauser, B.; de Reese, J. Experimental Determination of the Thermodynamic Parameters Affecting the Adsorption Behaviour and Dispersion Effectiveness of PCE Superplasticizers. Cem. Concr. Res. 2001, 40, 699-709. [CrossRef]

17. Yamada, K.; Hanehara, S.; Honma, K. Effects of the Chemical Structure on the Properties of Polycarboxylate-Type Superplasticizer. Cem. Concr. Res. 2000, 30, 197-207. [CrossRef]

18. Ohta, A.; Sugiyama, T.; Uomoto, T. Study of Dispersing Effects of Polycarboxylate-Based Dispersant on Fine Particles. In Proceedings of the 6th CANMET/ACI International Conference Superplasticizers and other Chemical Admixtures in Concrete 
(SP-195-14), Nice, France, 10-13 October 2000; Malhotra, V.M., Ed.; American Concrete Institute: Farmington Hills, MI, USA, 2000; pp. 211-228.

19. Winnefeld, F.; Becker, S.; Pakusch, J.; Gotz, T. Effects of the Molecular Architecture of Comb-Shaped Superplasticizers on Their Performance in Cementitious Systems. Cem. Concr. Compos. 2007, 29, 251-262. [CrossRef]

20. Kissa, E. Dispersions: Characterization. Testing and Measurement (Surfactant Science. No. 84); CRC Press/M. Dekker: New York, NY, USA, 15 June 1999.

21. Zingg, A.; Winnefeld, F.; Holzer, L.; Pakusch, J.; Becker, S.; Figi, R.; Gauckler, L. Interaction of Polycarboxylate-Based Superplasticizers with Cements Containing Different $C_{3}$ A Amounts. Cem. Concr. Compos. 2009, 31, 153-162. [CrossRef]

22. Bjömström, J.; Chandra, S. Effect of Superplasticizers on the Rheological Properties of Cements. Mater. Struct. Matriaux Constr. 2003, 36, 685-692. [CrossRef]

23. Flatt, R.J.; Houst, J.F. A Simplified View on Chemical Effects Perturbing the Action of Superplasticizers. Cem. Concr. Res. 2001, 31, 1169-1176. [CrossRef]

24. Kim, B.G.; Jiang, S.; Jolicoeur, C.; Aitcin, P.-C. The Adsorption Behavior of PNS Superplasticizer and its Relation to Fluidity of Cement Paste. Cem. Concr. Res. 2000, 30, 887-893. [CrossRef]

25. Pourchet, S.; Liautaud, S.; Rinaldi, D.; Pochard, I. Effect of the Repartition of the PEG Side Chains on the Adsorption and Dispersion Behaviors of PCP in Presence of Sulfate. Cem. Concr. Res. 2012, 42, 431-439. [CrossRef]

26. Uchikawa, H.; Sawaki, D.; Hanehara, S. Influence of Kind and Added Timing of Organic Admixture on the Composition, Structure and Property of Fresh Cement Pastes. Cem. Concr. Res. 1995, 25, 353-364. [CrossRef]

27. Jolicoeur, C.; Simard, M.A. Chemical Admixture-Cement Interactions: Phenomenology and Physico-Chemical Concepts. Cem. Concr. Compos. 1998, 20, 87-101. [CrossRef]

28. Grierson, L.H.; Knight, J.C.; Maharaj, R. The Role of Calcium Ions and Lignosulphonate Plasticiser in the Hydration of Cement. Cem. Concr. Res. 2005, 35, 631-636. [CrossRef]

29. Bombled, J.P. Influence of Sulfates on the Rheological Behavior of Cement Pastes and on their Evolution. In Proceedings of the 7th International Congress on the Chemistry of Cement, Paris, France, 1 January 1980; Volume VI, pp. 164-169.

30. Griesser, A. Cement-Superplasticizer Interactions at Ambient Temperatures: Rheology. Phase Composition. Pore Water and Heat of Hydratation of Cementitious Systems. Master's Thesis, Technische Wissenschaften ETH, Zürich, Switzerland, 2003.14820.

31. Taylor, H.F.W. Cement Chemistry; Academic: London, UK, 1990.

32. Jiang, S.; Kim, B.G.; Aitcin, P.C. Importance of Adequate Soluble Alkali Content to Ensure Cement/Superplasticizer Compatibility. Cem. Concr. Res. 1999, 29, 71-78. [CrossRef]

33. Hanehara, S.; Yamada, K. Rheology and Early Age Properties of Cement Systems. Cem. Concr. Res. 2008, 21, 175-195. [CrossRef]

34. Roberts, L.R. Dealing with Cement Admixture Interactions. In Proceedings of the 23rd Annual Convention of the Institute of Concrete Technology, Telford, UK, 11 April 1995.

35. Jolicoeur, C.; Nkinamubanzi, P.C.; Simard, M.A.; Piotte, M. Progress in Understanding the Functional Properties of Superplasticizer in Fresh Concrete. Am. Concr. Inst. 1994, SP148, 63-88.

36. Sakai, E.; Takayuki, K.; Tomomi, S.; Kiyoshi, A.; Masaki, D. Influence of Superplasticizers on the Hydration of Cement and the Pore Structure of Hardened Cement. Cem. Concr. Res. 2006, 36, 2049-2053. [CrossRef]

37. Nakajima, Y.; Yamada, K. The Effect of the Kind of Calcium Sulfate in Cements on the Dispersing Ability of Poly B -Napthalene Sulfonate Condensate Superplasticizer. Cem. Concr. Res. 2004, 34, 839-844. [CrossRef]

38. Plank, J.; Zhimin, D.; Keller, H.; Hössle, F.; Seidl, W. Fundamental Mechanisms for Polycarboxylate Intercalation into $C_{3}$ A Hydrate Phases and the Role of Sulfate Present in Cement. Cem. Concr. Res 2010, 40, 45-57. [CrossRef]

39. Hanna, E.; Ostiguy, M.; Khalifé, K.; Stoica, O.; Kim, B.G.; Bédard, C.; Saric-Coric, M.; Baalbaki, M.; Jiang, S.; Nkinamubanzi Aïtcin, P.C.; et al. The Importance of Superplasticizers in Modern Concrete Technology. In Proceedings of the CANMET/ACI International Conference on Superplasticizers and other Chemical Admixtures in Concrete, ACI (SP), Nice, France, 10-13 October 2000 .

40. Bensted, J. Cement science-is it simple? Cem. Lime Concr. 2001, 1, 6-18.

41. Janowska-Renkas, E. The Effect of Superplasticizers' Chemical Structure on Their Efficiency in Cement Pastes. Constr. Build. Mater. 2013, 38, 1204-1210. [CrossRef]

42. Grzeszczyk, S.; Sudoł, M. Effect of the Chemical Structures of Superplasticizers upon the Rheological Properties of Cement Pastes. In Proceedings of the 7th Canmet/ACI International Conference on Superplasticizers and Other Chemical Admixtures in Concrete, Berlin, Germany, 20-23 October 2003; Supplementary papers. pp. 363-377.

43. Scholz, E. Zum Einfluss des Calciumsulfates in Portlandzementen auf Konsistenz und Ansteifen von Normmörteln; Institut für Baustoffkunde und Materialprüfung: Hannover, Germany, 1992.

44. Bundyra-Oracz, G. Influence of Calcium Sulphate on the Reheological Behawior of Cement Paste. In Proceedings of the Conference, Dni betonu: Tradycja i nowoczesność, Stowarzyszenie Producentów Cementu, Wisła, Cracow, Poland, 9-11 October 2006. (In Polish)

45. Aïtin, P.C. Admixtures: Essentional Components of Modern Concrete. Cem. Lime Concr. 2006, 5, $227-284$.

46. Zingg, A.; Winnefeld, F.; Holzer, L.; Pakusch, J.; Becker, S.; Gauckler, L. Adsorption of Polyelectrolytes and Its Influence on the Rheology. Zeta Potential and Microstructure of Various Cement and Hydrate Phases. J. Colloid Interface Sci. 2008, 32, 301-312. [CrossRef] 
47. Morrison, R.T.; Boyd, R.N. Organic Chemistry; Państwowe Wydawnictwo Naukowe (PWN): Warsaw, Poland, 1985. (In Polish)

48. Kurdowski, W. Cement and Concrete Chemistry; Państwowe Wydawnictwo Naukowe (PWN): Warsaw, Poland, 2010. (In Polish)

49. Andersen, R.J.; Roy, D.M.; Gaidis, J.M. The Effect of Superplasticizers Molecular Weight on its Adsorption, and Dispersion of Cement. Cem. Concr. Res. 1988, 18, 980-986. [CrossRef]

50. Hsu, K.C.; Chiu, J.J.; Chen, S.D.; Tseng, Y.C. Effect of Addition Time of a Superplasticizer on Cement Adsorption and on Concrete Workabilyt. Cem. Concr. Compos. 1999, 21, 425-430. [CrossRef]

51. Yamada, K.; Ogawa, S.; Hanehara, S. Controlling of the Adsorption and Dispersing Force of Polycarboxylate-Type Superplasticizer by Sulfate Ion Concentration in Aqueous Phase. Cem. Concr. Res. 2001, 31, 375-383. [CrossRef]

52. Lewandowski, K. Globular and Micellar Polymer Structures-Computer Simulations Study. Ph.D. Thesis, Department of Quantum Physics, Faculty of Physics, Adam Mickiewicz University, Poznań, Poland, 2012.

53. Czarnecki, L. Domieszki do betonu-Możliwości i ograniczenia. Bud. Technol. Archit. Zesz. Spec. Domieszki Betonu 2003, 4-6. (In Polish)

54. Ohama, Y. Polymer-Based Admixtures. Cem. Concr. Compos. 1998, 20, 189-212. [CrossRef]

55. Rudnicki, T. Natural and Synthetic Admixtures Plasticize the Tail and Mechanisms of Their Interaction in the Concrete Mix. Autostrady Mag. 2004, 4, 22-25. 